\title{
Application and recalibration of soil water retention pedotransfer functions in a tropical upstream catchment: case study in Bengawan Solo, Indonesia
}

\author{
Andry Rustanto $^{1,2^{*}}$, Martijn J. Booij ${ }^{1}$, Henk Wösten ${ }^{3}$, Arjen Y. Hoekstra ${ }^{1,4}$ \\ ${ }^{1}$ Department of Water Engineering and Management, University of Twente, Drienerlolaan 57522 NB Enschede, the Netherlands. \\ 2 Department of Geography, University of Indonesia, Depok 16424 Jawa Barat, Indonesia. \\ ${ }^{3}$ Alterra Wageningen UR, Droevendaalsesteeg 36708 PB Wageningen, the Netherlands. \\ ${ }^{4}$ Institute of Water Policy, Lee Kuan Yew School of Public Policy, National University of Singapore, 469A Bukit Timah Road, 259770 \\ Singapore. \\ * Corresponding author. Tel: +62 217888 6680. Fax:+62 21786 6819. E-mail: rustanto@ui.ac.id; a.rustanto@utwente.nl
}

\begin{abstract}
Hydrological models often require input data on soil-water retention (SWR), but obtaining such data is laborious and costly so that SWR in many places remains unknown. To fill the gap, a prediction of SWR using a pedotransfer function (PTF) is one of the alternatives. This study aims to select the most suitable existing PTFs in order to predict SWR for the case of the upper Bengawan Solo (UBS) catchment on Java, Indonesia. Ten point PTFs and two continuous PTFs, which were developed from tropical soils elsewhere, have been applied directly and recalibrated based on a small soil sample set in UBS. Scatter plots and statistical indices of mean error (ME), root mean square error (RMSE), model efficiency (EF) and Pearson's correlation (r) showed that recalibration using the Shuffled Complex Evolution-University of Arizona (SCE-UA) algorithm can help to improve the prediction of PTFs significantly compared to direct application of PTFs. This study is the first showing that improving SWR-PTFs by recalibration for a new catchment based on around 50 soil samples provides an effective parsimonious alternative to developing a SWR-PTF from specifically collected soil datasets, which typically needs around 100 soil samples or more.
\end{abstract}

Keywords: Soil-water retention; Pedotransfer function recalibration; Tropical upstream catchment; Java Island.

\section{INTRODUCTION}

Water movement in the soil, particularly in the unsaturated zone, is one of the key processes in a wide range of studies, such as catchment scale hydrological modelling, agricultural crop management, forest management, soil nutrient cycle modelling and soil pollution modelling (Feddes et al., 2004). Soilwater retention (SWR) information is an important factor to predict the water storage and movement in the unsaturated zone (Hopmans and Schoups, 2006). Unfortunately, SWR information is not evenly available for every place on the earth (Hartemink, 2002; Minasny and Hartemink, 2011). The main reason is that laboratory and field measurements of SWR are labour intensive, time consuming and also require special equipment which leads to high costs (Durner and Lipsius, 2006). Therefore, information about SWR in many places remains unknown. To fill gaps in SWR data, prediction using easy to measure or readily available soil property information through pedotransfer functions (PTF) could be one solution (Bouma, 1989; Wösten et al., 2001). This study aims to determine a suitable ready-to-use PTF in order to fill SWR data gaps in a tropical upstream catchment, the upper Bengawan Solo (UBS) catchment, on Java, Indonesia.

According to Sulaeman et al. (2013) who studied the availability of soil data in Indonesia, many areas on Java still lack published SWR information, particularly for upstream catchments such as UBS. In addition, it is also hard to find SWR information from local unpublished soil datasets, for instance, thesis and research manuscripts from local universities and previous soil survey reports. On the other hand, the current situation highlights the fact that UBS is environmentally deteriorating due to land use and climate changes. This leads to an increase of the frequency and severity of hazardous events such as floods, drought, landslides and soil erosion (Lavigne and
Gunnell, 2006) and this calls for studies that require SWR information as one of the key elements.

Progress on PTF development over recent decades shows some options for selecting ready-to-use PTFs (Pachepsky and Rawls, 2004) in the context of SWR prediction. However, the selection of a suitable PTF is not straightforward. Some considerations need to be taken into account, e.g. a PTF might be inadequate for an application that requires soil property data at a specific point and it is not recommended to use PTFs for extrapolation purposes, in which the dataset for prediction is outside of the data range for which the PTF has been developed (Wösten et al., 2001). The latter consideration has also been discussed further by, for instance, Tomasella and Hodnett (2004) and Minasny and Hartemink (2011). They pointed out the differences between soils in temperate and tropical regions. Minasny and Hartemink (2011) reported that soils in tropical regions generally have a higher clay content, lower cation exchange capacity, higher bulk density and lower SWR at $-10 \mathrm{kPa}$ and $-1500 \mathrm{kPa}$ compared with soils in temperate regions. In addition, Tomasella and Hodnett (2004) concluded that the differences in physical and chemical characteristics of soils lead to differences in hydraulic properties of soils between tropical and temperate regions. Therefore, PTFs for predicting SWR that were developed from temperate soils most probably will not be suitable for application to tropical soils, and vice versa, or they could be applied but with great caution (Hodnett et al., 1995; Wösten et al., 2001).

Literature shows that more soil datasets are available for temperate regions than for tropical regions (Hartemink, 2002; Minasny and Hartemink, 2011). Therefore, most of the existing PTFs in the literature were developed based on temperate soil datasets (Tomasella and Hodnett, 2004). This limits the number of PTFs which can be selected for application in tropical regions. Furthermore, there is still the possibility of inadequate 
PTF application for a region even though the PTFs has been developed from a soil dataset acquired from a similar geographical domain (e.g. a similar tropical or temperate region). This PTF inadequacy occurs probably due to differences in specific geographical or geomorphological characteristics between the region of PTF development and the region in which PTF is used (McBratney et al., 2002). Alternatively, new PTFs from a local soil dataset can be developed but it might not be a good option for many tropical regions since the prerequisite of large soil datasets can hardly be met, as in the case for our study area.

Instead of developing a new PTF, optimization of existing PTFs through recalibration with limited local soil datasets is a possibility. Most probably, the published PTFs already contain the essential predictors; however the parameters used probably need to be adjusted. An example of a successful recalibration of an established PTF has been carried out for the prediction of the saturated hydraulic conductivity (Abdelbaki, 2015), while for the prediction of SWR characteristics no example could be found to the best of our knowledge. The novelty of this study is to include a recalibration step in both point and continuous SWR-PTF application for utilization in a tropical region.

The objective of this study is therefore to select the most suitable existing PTFs in order to predict the soil-water retention in UBS, both by direct application and after recalibration. At this aim, four specific objectives are defined: (1) to list the existing published PTFs that are available to predict SWR in UBS; (2) to evaluate the applicability and direct application performance of the selected PTFs; (3) to recalibrate the selected PTFs with a local soil dataset; (4) to compare the performance of the selected PTFs, before (direct application) and after recalibration.

\section{MATERIAL AND METHODS \\ Study area}

The upper Bengawan Solo (UBS) catchment is located mainly in central Java province with small parts in Yogyakarta province, Indonesia (Figure 1). The catchment is between longitudes $110^{\circ} 26^{\prime} 45.6^{\prime \prime}-111^{\circ} 13^{\prime} 22.8^{\prime \prime} \mathrm{E}$ and latitudes $7^{\circ} 30^{\prime}$ $50.076^{\prime \prime}-8^{\circ} 6^{\prime} 51.264 " \mathrm{~S}$. The surface area is $3,306.5 \mathrm{~km}^{2}$ or around $20.5 \%$ of the total area of the Bengawan Solo river catchment, the biggest catchment on Java.

According to van Bemmelen (1949), UBS is located on three geological formations, those are quaternary volcanic, pretertiary and tertiary sediment. The volcanic formations are located in the western and eastern parts as the result of the existence of the Merapi-Merbabu volcanoes in the west and the Lawu volcano in the east. The sedimentary formations were formed as uplifted and folded structures in the south, and fluvio-volcanic plain in the central part. The predominant climate in the study area is a monsoon type with a dry season from April to August and a rainy season from September to March. The climate in UBS is determined by elevation and general slope orientation that faces monsoon wind direction (Vernimmen and BMKG, 2013). The annual rainfall varies spatially from around $2000 \mathrm{~mm}$ in the centre of the catchment (elevation $80-100 \mathrm{~m}$ ), to around $2600-3000 \mathrm{~mm}$ at the slope to the peak of both volcanoes (elevation 950-3000 m). However, lower annual rainfall has occurred in the southern part of UBS, which is around 1500-1800 $\mathrm{mm}$ (elevation 170-450 m). The annual mean temperature ranges from $26^{\circ} \mathrm{C}$ at the lowest elevation (around $100 \mathrm{~m}$ ) in Surakarta municipality to $14.3^{\circ} \mathrm{C}$ at the highest elevation $(3265 \mathrm{~m}$ ) on the top of the Lawu volcano.

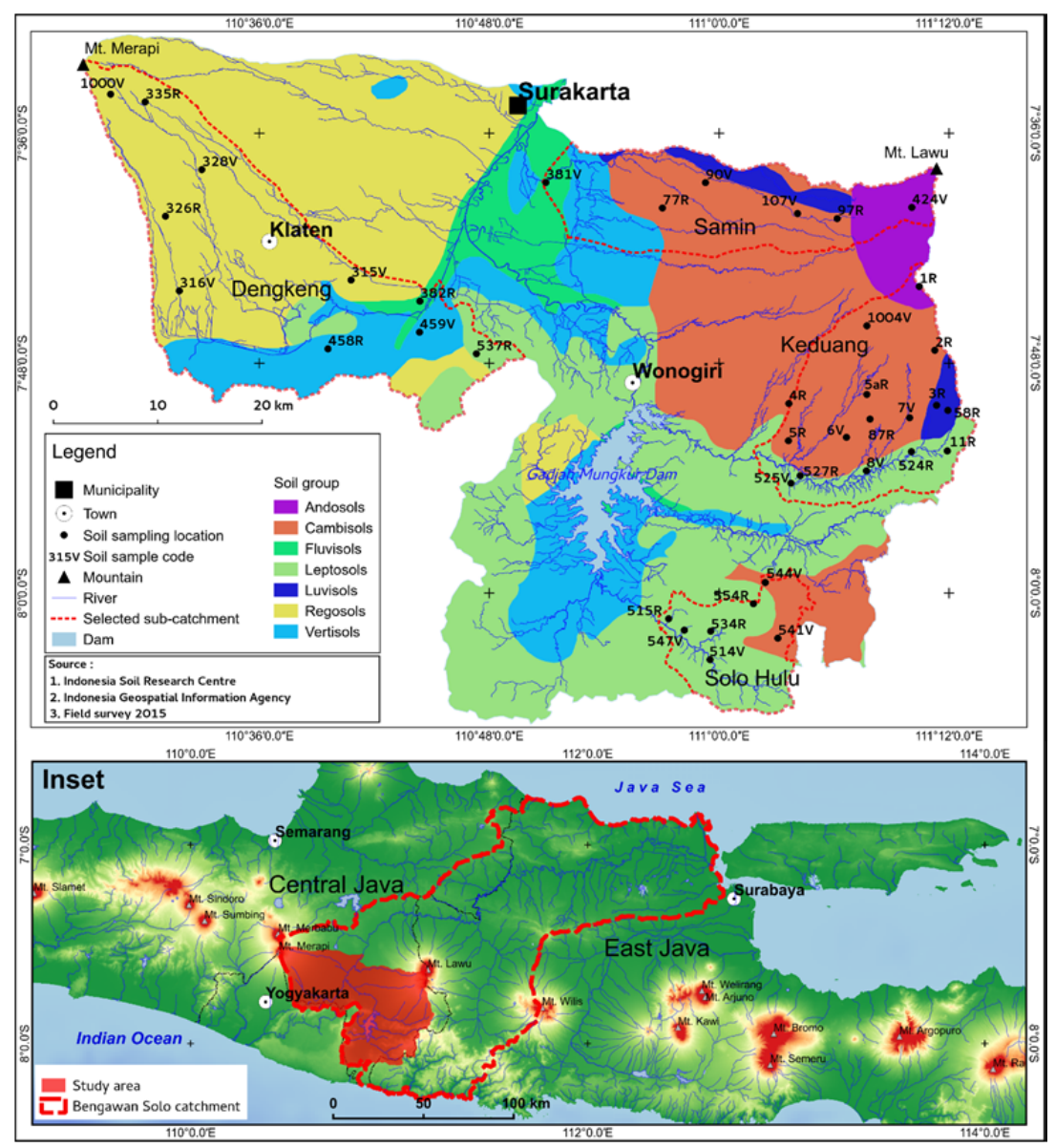

Fig. 1. The upper Bengawan Solo (UBS) catchment and soil sampling locations. 
Soil formation processes in UBS are mainly influenced by climatic and hydrological factors. As reported by Tan (2008), the major factor recognized as influencing soil forming processes in the area are podzolization in the high altitude region (elevation above $1500 \mathrm{~m}$ ) and laterization in the low altitude region (elevation below $150 \mathrm{~m}$ ). Both processes - podzolization and laterization - occur simultaneously in the area between low and high altitudes, namely the upland or transitional zone. According to the soil group classification of the Indonesia Soil Research Institute (Suhardjo and Soepraptohardjo, 1981), soils in UBS are dominated by Latosol, Grumusol, Alluvial, Regosol, Mediteran, Andosol and Litosol. The UBS soil group distribution is shown in Figure 1 as well.

\section{Soil dataset}

For the purpose of SWR-PTF evaluation and recalibration, soil samples were collected from 84 soil horizons in UBS during the end of the rainy season in March and April 2015. The sampling locations were determined stratified-randomly in four sub-catchments in such a way that they represent the major landscape units of UBS (Figure 1). One sub-catchment represents a volcanic and fluvio-volcanic landscape unit in the west (Dengkeng), two other sub-catchments represent volcanic and fluvio-volcanic landscapes in the east (Samin and Keduang) and one sub-catchment represents an uplifted-folded sediment landscape in the south (Solo Hulu). The landscape unit map was generated based on the principle of soil and terrain (SOTER) unit development (van Engelen and Ting-tiang, 1995; Wösten et al., 2013) through a spatial overlay of the soil, slope, elevation and current land use / land cover maps. The dataset for the landscape unit map generation was obtained from the Catchment Management Office of Solo (BPDAS Solo) in Surakarta.

Both disturbed and undisturbed soil samples were collected from 29 locations in UBS. At 26 locations, samples were taken from three soil layers at depth intervals of $0-10 \mathrm{~cm}, 10-20 \mathrm{~cm}$ and $20-40 \mathrm{~cm}$. At another three locations, soil samples were only taken from the first and second layers due to a thin soil layer. Each disturbed soil sample was approximately $0.5 \mathrm{~kg}$ of soil in a plastic bag, while undisturbed soil samples were taken by using a soil ring cylinder with the inner diameter of $7.6 \mathrm{~cm}$ and height of $4 \mathrm{~cm}$. Disturbed soil samples were used to determine: (1) particle size distribution using the sieve-hydrometer method (Gee and Bauder, 1986) after the soil samples were airdried, organic matter was eliminated using $\mathrm{H}_{2} \mathrm{O}_{2}$ and was dispersed using $\mathrm{HCl}(0.002 \mathrm{~N})$ to anticipate any existence of allophane mineral (Maeda et al., 1977) due to the existence of the active volcanoes; (2) organic carbon content using the wet oxidation method (Nelson and Sommers, 1996); (3) soil pH $\left(\mathrm{H}_{2} \mathrm{O}\right)$ using the 1:5 soil-water suspension method (Rayment and Higginson, 1992). From the undisturbed soil samples, information about the soil bulk density was obtained using the core method (Grossman and Reinsch, 2002), while volumetric SWR at matric potentials of $0 \mathrm{kPa},-1 \mathrm{kPa},-10 \mathrm{kPa},-33 \mathrm{kPa}$ was measured using the pressure-plate apparatus method (Richards and Fireman, 1943), and volumetric SWR at a matric potential of $-1500 \mathrm{kPa}$ was measured using the pressuremembrane apparatus method (Richards, 1947). A combination of pressure-plate and pressure-membrane apparatus was used in order to minimize the SWR measurement error due to the lack of contact between the plate and the soil, and low plate conductance as found by Bittelli and Flury (2009). For the soil particle size distribution measurement, the sieve-hydrometer method was selected due to its commonly used, rapid process, simplicity and low costs. However, the method might be less precise compared with another popular method, i.e. the pipette method (Gee and Bauder, 1986). Nevertheless, soil particle distribution information obtained from both methods was not found to result insignificantly different predictions of the SWR capacity (Beretta et al., 2014).

All laboratory analyses were conducted in the Centre for Agricultural Technology Assessment (BPTP) in Yogyakarta, Indonesia between March and June 2015. In addition to these field sampling data, a soil dataset from Nugroho (2015) and Oldhoff (2015) consisting of 10 samples from Keduang subcatchment was also included into our dataset. Summary statistics of the soil dataset of UBS including a Pearson's correlation matrix between its soils properties are shown in Table 1 and Table 2. The textural distribution is shown in Figure 2.

Table 1. Summary statistics of the UBS soil dataset $(\mathrm{N}=94)$.

\begin{tabular}{l|ccccccccccc}
\hline & $\begin{array}{c}\text { Sand } \\
(\%)\end{array}$ & $\begin{array}{c}\text { Silt } \\
(\%)\end{array}$ & $\begin{array}{c}\text { Clay } \\
(\%)\end{array}$ & $\begin{array}{c}\text { OC } \\
(\mathrm{g} / 100 \mathrm{~g})\end{array}$ & $\begin{array}{c}\text { Bulk density } \\
\left(\mathrm{g} . \mathrm{cm}^{-3}\right)\end{array}$ & $\mathrm{pH}$ & $\theta_{0 k P a}$ & $\theta_{-1 \mathrm{kPa} a}$ & $\theta_{-10 \mathrm{kPa}}$ & $\theta_{-33 \mathrm{kPa}}$ & $\theta_{-1500 \mathrm{kPa}}$ \\
\hline Minimum & 4.0 & 2.0 & 7.0 & 0.20 & 0.78 & 4.11 & 0.42 & 0.41 & 0.26 & 0.22 & 0.16 \\
Maximum & 79.0 & 55.0 & 79.0 & 7.27 & 1.41 & 7.41 & 0.77 & 0.76 & 0.47 & 0.40 & 0.20 \\
Median & 20.5 & 30.5 & 45.5 & 0.94 & 1.14 & 5.59 & 0.53 & 0.51 & 0.41 & 0.29 & 0.18 \\
Mean & 27.2 & 30.7 & 42.4 & 1.20 & 1.13 & 5.52 & 0.53 & 0.51 & 0.40 & 0.29 & 0.18 \\
SD & 20.4 & 9.8 & 22.7 & 1.02 & 0.15 & 0.64 & 0.06 & 0.06 & 0.05 & 0.04 & 0.01 \\
\hline
\end{tabular}

SD: standard deviation; OC: Organic carbon content; $\theta_{0 \mathrm{kPa}}, \theta_{-1 \mathrm{kPa}}, \theta_{-10 \mathrm{kPa}}, \theta_{-33 \mathrm{kPa}}$ and $\theta_{-1500 \mathrm{kPa}}$ : volumetric SWR at matric potential of $0 \mathrm{kPa},-1 \mathrm{kPa},-10 \mathrm{kPa},-33 \mathrm{kPa}$ and $-1500 \mathrm{kPa}\left(\mathrm{cm}^{3} \cdot \mathrm{cm}^{-3}\right)$

Table 2. Pearson's correlation matrix between soil properties of the UBS soil dataset $(N=94)$.

\begin{tabular}{|c|c|c|c|c|c|c|c|c|c|}
\hline & Sand & Silt & Clay & Bulk density & $\mathrm{OC}$ & $\mathrm{pH}$ & $\theta_{-10 k P a}$ & $\theta_{-33 k P a}$ & $\theta_{-1500 k P a}$ \\
\hline Sand & 1.00 & & $* * *$ & $* *$ & $* *$ & $*$ & & $*$ & \\
\hline Silt & 0.01 & 1.00 & $* * *$ & * & $* * *$ & & * & & \\
\hline Clay & -0.90 & -0.44 & 1.00 & $* * *$ & $* * *$ & * & & * & \\
\hline Bulk density & -0.29 & -0.20 & 0.35 & 1.00 & $* * *$ & * & $* * *$ & $* * *$ & $* * *$ \\
\hline Organic content & 0.28 & 0.37 & -0.41 & -0.52 & 1.00 & & $*$ & $*$ & $* *$ \\
\hline $\mathrm{pH}$ & -0.21 & -0.01 & 0.19 & 0.18 & -0.04 & 1.00 & & & \\
\hline$\theta_{-10 k P a}$ & -0.13 & 0.19 & 0.04 & -0.51 & 0.24 & 0.12 & 1.00 & $* * *$ & $* * *$ \\
\hline$\theta_{-33 k P a}$ & 0.21 & 0.05 & -0.21 & -0.49 & 0.23 & 0.16 & 0.63 & 1.00 & $* * *$ \\
\hline$\theta_{-1500 k P a}$ & 0.04 & 0.13 & -0.09 & -0.44 & 0.27 & 0.02 & 0.67 & 0.70 & 1.00 \\
\hline
\end{tabular}

OC: Organic carbon content; $\theta_{0 \mathrm{kPa}}, \theta_{-1 \mathrm{kPa}}, \theta_{-10 \mathrm{kPa}}, \theta_{-33 \mathrm{kPa}}$ and $\theta_{-1500 \mathrm{kPa}}$ : volumetric SWR at matric potential of $0 \mathrm{kPa}$, $-1 \mathrm{kPa}$, $-10 \mathrm{kPa},-33 \mathrm{kPa}$ and $-1500 \mathrm{kPa}\left(\mathrm{cm}^{3} \cdot \mathrm{cm}^{-3}\right) ; * * *$ and $* * *$ : significant at $\mathrm{p}<0.05, \mathrm{p}<0.01$ and $\mathrm{p}<0.001$. 


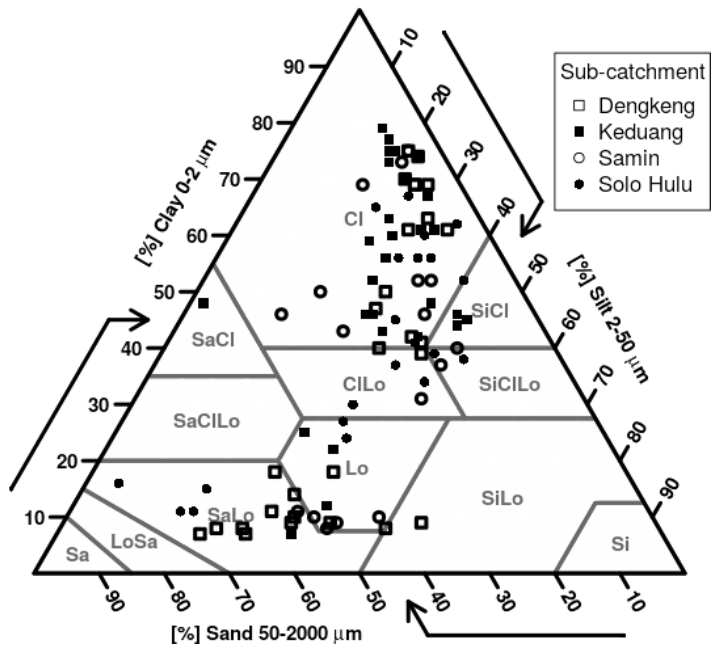

Fig. 2. Textural class distribution of soil samples taken from the UBS catchment.

\section{PTF selection}

PTFs for SWR estimation can be distinguished based on the geographical domain of the soil dataset for PTF development (i.e., international and local / site-specific soil dataset). Furthermore, the PTFs can also be distinguished based on the type of prediction, i.e., point and continuous PTFs (Wösten et al., 2001). Both point and continuous PTFs are evaluated in this study limited to PTFs that were developed for tropical regions.

In particular, we look at some PTFs that have been developed from tropical soil datasets summarized by Tomasella and Hodnett (2004), Minasny and Hartemink (2011), Botula et al. (2012) and Nguyen et al. (2015). Furthermore, PTF selection was also limited to PTFs that use soil properties as predictors which can be found in or can be predicted using our dataset. Table 3 gives a list of both point and continuous PTFs that have been selected for this evaluation study. One continuous PTFs mentioned in the study of Minasny and Hartemink (2011) require the cation exchange capacity (CEC) as one of the predictors. Because our dataset does not have CEC information from UBS, the commonly used tropical soil CEC-PTF developed by Bell and van Keulen (1995) was utilized.

Continuous PTFs estimate parameters of the widely used van Genuchten (vG) soil-water release curve model (van Genuchten, 1980):

$$
\theta=\theta_{r}+\frac{\theta_{s}-\theta_{r}}{\left[1+(\alpha h)^{n}\right]^{m}}
$$

where $\theta$ is the predicted SWR, h is the soil-water matric potential, $\theta_{r}$ is the residual water content, $\theta_{s}$ is the saturated water content, $n, m$ and $\alpha$ are empirical parameters, with $m=1-1 / n$. More information about the vG parameters can be found in van Genuchten et al. (1991). The predictions of selected PTFs in gravimetric unit were converted into volumetric unit by multiplying it with the soil bulk density.

Table 3. List of selected PTFs used for evaluation and recalibration against the UBS soil dataset.

\begin{tabular}{|c|c|}
\hline Source & PTFs \\
\hline Pidgeon (1972) & $\begin{array}{l}w_{-10 \mathrm{kPa}}(\%)=(7.38+0.16 \mathrm{Si}+0.3 \mathrm{Cl}+1.5 \mathrm{SOM}-2.54) 0.91^{-1} \\
w_{-33 \mathrm{kPa}}(\%)=(7.38+0.16 \mathrm{Si}+0.3 \mathrm{Cl}+1.5 \mathrm{SOM}-3.77) 0.95^{-1} \\
w_{-1500 \mathrm{kPa}}(\%)=-4.19+0.19 \mathrm{Si}+0.39 \mathrm{Cl}+0.9 \mathrm{SOM}\end{array}$ \\
\hline Lal (1979) & $\begin{array}{l}w_{-10 \mathrm{kPa}}(\mathrm{g} / \mathrm{g})=0.102+0.003 \mathrm{Cl}, w_{-33 \mathrm{kPa}}(\mathrm{g} / \mathrm{g})=0.065+0.004 C l \\
w_{-1500 \mathrm{kPa}}(\mathrm{g} / \mathrm{g})=0.006+0.003 C l\end{array}$ \\
\hline Aina and Periaswamy (1985) & $w_{-33 \mathrm{kPa}}(\%)=67.88+0.55 \mathrm{Sa}-0.13 \mathrm{BD} \mathrm{Sa}, w_{-1500 \mathrm{kPa}}(\%)=2.13+0.31 \mathrm{Cl}$ \\
\hline $\begin{array}{l}\text { Arruda et. al. (1987) in Tomasella and Hodnett } \\
\text { (2004) }\end{array}$ & $w_{-33 \mathrm{kPa}}(\%)=9.93+0.29(\mathrm{Cl}+\mathrm{Si}), w_{-1500 \mathrm{kPa}}(\%)=1.07+0.27(\mathrm{Cl}+\mathrm{Si})$ \\
\hline Dijkerman (1988) & $w_{-33 \mathrm{kPa}}(\%)=36.97-0.35 \mathrm{Sa}, w_{-1500 \mathrm{kPa}}(\%)=0.74+0.39 \mathrm{Cl}$ \\
\hline van den Berg et al. (1997) & $\begin{array}{l}\theta_{-10 \mathrm{kPa}}(\%)=10.88+0.347 \mathrm{Cl}+0.211 \mathrm{Si}+1.7560 \mathrm{C} \\
\theta_{-1500 \mathrm{kPa}}(\%)=(0.334 \mathrm{Cl}+0.104 \mathrm{Si}) \mathrm{BD}\end{array}$ \\
\hline van den Berg et al. (1997)* & $\begin{array}{l}\theta_{r}(\%)=0.38 C l B D, \ln \alpha\left(\mathrm{kPa}^{-1}\right)=-0.627 \\
\theta_{s}(\%)=84.1-0.206 C l B D-0.322(S a+S i) B D \\
m=0.503-(0.0027(S i+C l)+0.0660 C-0.0094 C E C) B D\end{array}$ \\
\hline Hodnett and Tomasella (2002)* & $\begin{array}{l}\theta_{r}(\%)=22.733-0.164 S a+0.235 C E C-0.831 p H+0.0018 C l^{2}+0.0026 S a C l \\
\theta_{s}(\%)=81.799+0.099 C l-31.420 B D+0.018 C E C+0.451 p H-0.0005 S a C l \\
\ln \alpha\left(x 100 \mathrm{kPa}^{-1}\right)=-2.294-3.526 S i+2.440 O C-0.076 C E C-11.331 p H+0.019 S i^{2} \\
\ln n(x 100)=62.986-0.883 C l-0.529 O C+0.593 p H+0.007 C l^{2}-0.014 S a S i\end{array}$ \\
\hline $\begin{array}{l}\text { Oliveira et al. (2002) in Tomasella and Hodnett } \\
\text { (2004) }\end{array}$ & $\begin{array}{l}w_{-33 \mathrm{kPa}}\left(\mathrm{kg} \mathrm{kg}^{-1}\right)=0.00333 \mathrm{Si}+0.00387 \mathrm{Cl} \\
w_{-1500 \mathrm{kPa}}\left(\mathrm{kg}^{\mathrm{kg}} \mathrm{kg}^{-1}\right)=0.00038 \mathrm{Sa}+0.00153 \mathrm{Si}+0.00341 \mathrm{Cl}-0.03086 \mathrm{BD}\end{array}$ \\
\hline Adhikary et al. (2008) & $\begin{array}{l}\theta_{-10 \mathrm{kPa}}(\%)=62.5-0.58 \mathrm{Sa}-0.21 \mathrm{Si}, \theta_{-33 \mathrm{kPa}}(\%)=56.37-0.51 \mathrm{Sa}-0.27 \mathrm{Si} \\
\theta_{-1500 \mathrm{kPa}}(\%)=0.71+0.44 \mathrm{Cl}\end{array}$ \\
\hline Minasny and Hartemink (2011) & $\begin{array}{l}\theta_{-10 \mathrm{kPa}}(\%)=59.9-8.78 \mathrm{BD}-0.31 \mathrm{Sa}, \theta_{-33 \mathrm{kPa}}(\%)=56.5-7.49 \mathrm{BD}-0.34 \mathrm{Sa} \\
\theta_{-1500 \mathrm{kPa}}(\%)=7.95+0.860 \mathrm{C}+0.4 \mathrm{Cl}-0.004(\mathrm{Cl}-37.7)^{2}\end{array}$ \\
\hline Botula (2013) & $\begin{array}{l}w_{-33 \mathrm{kPa}}\left(\mathrm{g} \cdot \mathrm{g}^{-1}\right)=0.4193-0.0035 S a \\
w_{-1500 \mathrm{kPa}}\left(\mathrm{g} \cdot \mathrm{g}^{-1}\right)=0.0841-0.00159 \mathrm{Sa}+0.0021 C l+0.0779 B D\end{array}$ \\
\hline
\end{tabular}

*continuous PTF; $w_{-10 \mathrm{kPa}}, w_{-33 \mathrm{kPa}}, w_{-1500 \mathrm{kPa}}$ and $\theta_{-10 \mathrm{kPa}}, \theta_{-33 \mathrm{kPa}}, \theta_{-1500 \mathrm{kPa}}$ : gravimetric and volumetric SWR at matric potential of $-10 \mathrm{kPa}$, $-33 \mathrm{kPa}$ and $-1500 \mathrm{kPa}$, respectively; $\mathrm{Sa}, \mathrm{Si}, \mathrm{Cl}, O C$ : sand, silt, clay, organic carbon content in $\mathrm{g} \mathrm{g}^{-1} \mathrm{x} \mathrm{100;}$; $O M$ : soil organic matter $=1.724 O C$, in $\mathrm{g} \mathrm{g}^{-1} \times 100$; BD: soil bulk density in $\mathrm{g} \mathrm{cm}^{-3}$, CEC: cation exchange capacity in $\mathrm{cmol} \mathrm{kg}^{-1}$; $\mathrm{pH}$ : soil acidity (unit less). 
Application and recalibration of soil water retention pedotransfer functions in a tropical upstream catchment

\section{Evaluation of PTF for direct application and recalibration}

Evaluation of selected PTFs against the UBS soil dataset in this study was done in four steps and using two evaluation criteria, namely PTF applicability and performance. The first step is to determine the applicability of selected PTFs; the second step is to assess the performance of selected PTFs in its direct application, the third step is to recalibrate selected PTFs; and the fourth step is to determine the performance of the recalibrated PTFs and compare it with the performance of the direct application. According to Tomasella and Hodnett (2004), applicability is described as the portion of the soil dataset that is used for PTF evaluation which has predictors (e.g. soil texture distribution, bulk density and percentage of organic content) within the range of predictors used for PTF development. Performance is described as the correspondence between measured and predicted values and recalibration is the optimization of the PTF in order to improve the prediction performance.

In the first and second steps, all available soil datasets from the study area were used, while for the third and fourth steps, the soil dataset of UBS was split equally into two parts in such a way that both datasets have similar statistical properties and are equally distributed in the four sub-catchments (Figure 1). The first half of the dataset was used in the third step for recalibration and the second half of the dataset in the fourth step for validation of the recalibrated PTFs. The location of both datasets are shown in Fig. 1, where " $R$ " indicates the recalibration dataset and " $V$ " indicates the validation dataset. For the performance comparison in the fourth step, the validation was done using both original and recalibrated selected PTFs.

For the purpose of recalibration of the selected PTFs, the Shuffled Complex Evolution-University of Arizona algorithm (SCE-UA) (Duan et al., 1994) was used. The algorithm works based on an evolutionary procedure that evolves the model parameter sets simultaneously towards a better solution by converging the objective function to its global optimum (Blasone et al., 2006). Recalibration was run with minimally hundred iterations until the optimum value of the objective function was found. For the point PTF recalibration, the reference values used are the measured SWR at $-10 \mathrm{kPa},-33 \mathrm{kPa}$ and $-1500 \mathrm{kPa}$ of the UBS recalibration dataset. For recalibration of the continuous PTF, the vG parameters $\left(\theta_{r}, \theta_{s}, n\right.$ and $\left.\alpha\right)$ of the reference SWR curves were obtained by the RETC (RETention Curve) code (van Genuchten et al., 1991). Summary statistics of vG parameters defined using the SWR curves modelled by the RETC algorithm are shown in Table 4. In addition, Table 5 shows the mutual Pearson's correlation coefficients between the vG parameters, between the predictors and, between $\mathrm{vG}$ parameters and the predictors.
Table 4. Summary statistics of $v G$ parameters of the UBS soil samples $(\mathrm{N}=47)$

\begin{tabular}{l|cccc}
\hline & $\theta_{r}$ & $\theta_{s}$ & $\alpha$ & $n$ \\
\hline Minimum & 0.000 & 0.421 & 0.005 & 1.144 \\
Maximum & 0.198 & 0.784 & 0.198 & 2.536 \\
Median & 0.170 & 0.528 & 0.013 & 1.686 \\
Mean & 0.153 & 0.531 & 0.030 & 1.717 \\
SD & 0.050 & 0.065 & 0.039 & 0.342 \\
\hline
\end{tabular}

$\theta_{r}$ : residual water content; $\theta_{s}$ : saturated water content; $\alpha$ : the inverse of the $\mathrm{h}$ (soil-water matric potential) value half way between $\theta_{r}$ and $\theta_{s} ; n$ : shape of water retention curve.

The PTF applicability was described by an applicability index:

Applicability index $=\frac{x_{p}}{x_{\text {tot }}} 100 \%$

where $x_{p}$ is the number of samples used for PTF evaluation which has predictors within the range of predictors used for PTF calibration, $x_{t o t}$ is the total number of samples used for PTF evaluation.

The PTF performance was evaluated graphically by plotting measured and predicted values and quantitatively by calculating the mean error (ME), the root mean square error (RMSE) and the modelling efficiency (EF) between the measured and the predicted SWR according to the following equation:

$M E=\frac{\sum_{1}^{n}\left(\hat{y}_{i}-y_{i}\right)}{n}$

$R M S E=\sqrt{\frac{\sum_{1}^{n}\left(\hat{y}_{i}-y_{i}\right)^{2}}{n}}$

$E F=\frac{\sum_{1}^{n}\left(y_{i}-\bar{y}_{l}\right)^{2}-\sum_{1}^{n}\left(\hat{y}_{i}-y_{i}\right)^{2}}{\sum_{1}^{n}\left(y_{i}-\bar{y}_{l}\right)^{2}}$

where $y_{i}$ is the measured value, $\hat{y}_{i}$ is the predicted value, $\bar{y}_{l}$ is the mean of the measured values, $\overline{\hat{y}}_{i}$ is the mean of the predicted values and $\mathrm{n}$ is the total number of observations.

The ME value indicates the average tendency of underestimation (negative) or overestimation (positive) of the PTF prediction results against the measured values. RMSE and EF values indicate the overall prediction error and predictive power of the PTF, respectively. A perfect match of PTF predicted and related measured values will be indicated by ME and RMSE values of 0 and an EF value of 1 . We used the above three evaluation criteria because they are commonly used in PTF evaluation studies and also a preliminary assessment prior to this study concluded that a combination of ME, RMSE and EF

Table 5. Mutual Pearson's correlation coefficients between vG parameters and predictors, between vG parameters and between predictors, of the UBS soil samples $(\mathrm{N}=47)$.

\begin{tabular}{|c|c|c|c|c|c|c|c|c|c|c|}
\hline & Sand & Silt & Clay & Bulk density & $\mathrm{OC}$ & $\mathrm{pH}$ & $\theta_{r}$ & $\theta_{s}$ & $\alpha$ & $n$ \\
\hline Sand & 1.00 & & $* * *$ & $* *$ & $* *$ & $*$ & ** & $* * *$ & $* * *$ & $* * *$ \\
\hline Silt & 0.01 & 1.00 & $* * *$ & $*$ & $* * *$ & & & $*$ & $* * *$ & \\
\hline Clay & -0.90 & -0.44 & 1.00 & $* * *$ & $* * *$ & $*$ & $*$ & $* * *$ & & $* * *$ \\
\hline Organic content & 0.28 & 0.37 & -0.41 & -0.52 & 1.00 & & & $* * *$ & & \\
\hline $\mathrm{pH}$ & 0.21 & 0.01 & 0.20 & 0.20 & -0.04 & 1.00 & & $*$ & $* *$ & \\
\hline$\theta_{r}$ & -0.31 & 0.05 & 0.26 & 0.15 & 0.02 & -0.04 & 1.00 & $*$ & $* * *$ & $* * *$ \\
\hline$\theta_{s}$ & 0.41 & 0.18 & -0.45 & -0.84 & 0.54 & -0.20 & -0.18 & 1.00 & $* *$ & $* * *$ \\
\hline$\alpha$ & 0.43 & -0.11 & -0.34 & -0.14 & 0.04 & -0.29 & -0.59 & 0.28 & 1.00 & $* * *$ \\
\hline$n$ & -0.44 & 0.03 & 0.39 & 0.28 & -0.16 & -0.06 & 0.71 & -0.4 & -0.61 & 1.00 \\
\hline
\end{tabular}

OC: Organic carbon content; SD: standard deviation; *significant at $\mathrm{p}<0.05 ; * *$ significant at $\mathrm{p}<0.01 ; * * *$ significant at $\mathrm{p}<0.001 ; \theta_{r}:$ residual water content; $\theta_{s}$ : saturated water content; $\alpha$ : the inverse of the $h$ (soil-water matric potential) value half way between $\theta_{r}$ and $\theta_{s} ; n$ : shape of water retention curve. 
is the most suitable one to be used in the objective function (OF) for PTF recalibration. The objective function (OF) aimed to minimize ME and RMSE, and to maximize EF:

$O F=\sqrt{M E^{2}+R M S E^{2}+(1-E F)^{2}}$

In addition, the Pearson's correlation coefficient (r) was also used to determine the relation between predicted and measured SWR in UBS:

$r=\frac{\sum_{1}^{n}\left(\hat{y}_{i}-\overline{\hat{y}}_{i}\right)\left(y_{i}-\bar{y}_{l}\right)}{\sqrt{\sum_{1}^{n}\left(\hat{y}_{i}-\overline{\hat{y}}_{i}\right)^{2} \sum_{1}^{n}\left(y_{i}-\bar{y}_{l}\right)^{2}}}$

The better the PTF prediction, the smaller the OF value and the closer the $r$ value to 1 . OF and $r$ values are regarded as the final PTF evaluator in this study.

\section{RESULTS AND DISCUSSION Applicability of selected PTFs}

Applicability of ten selected point PTFs and two continuous PTFs defined by means of the applicability index between soils datasets of selected PTFs and of UBS are presented in Table 6.

Table 6 shows that selected PTFs cover a relatively high portion of the UBS soil dataset, except the PTF of Aina and Periaswamy (1985). This is probably because some PTFs were developed based on international datasets and also from large national soil datasets. A relatively high applicability index is also shown by PTFs that were developed from a local dataset, most probably because those regions have similar conditions as UBS. In summary, PTFs that were developed from international datasets have a higher applicability index than PTFs developed from national and local datasets.

In general, almost all selected PTFs are highly applicable to the UBS soil dataset regarding the input predictors (i.e. soil texture distribution, soil bulk density and percentage of organic content). However, the applicability indices do not reflect the performance of PTFs for application in UBS, since the performance of a PTF can only be tested with a validation process. Nevertheless, the applicability index most probably can help to explain the performance of the selected PTFs in predicting SWR in UBS.

\section{Performance of selected PTFs in direct application Point PTFs}

Performance of selected point PTFs in predicting SWR at $-10 \mathrm{kPa},-33 \mathrm{kPa}$ and $-1500 \mathrm{kPa}$ for the UBS dataset is shown in Figure 3 and Table 7.

In general, scatterplots in Figure 3 show large biases in all directions for SWR at $-10 \mathrm{kPa}$ predicted by selected PTFs of Pidgeon (1972), Lal (1979) and Adhikary et al. (2008) as the first group, and of van den Berg et al. (1997) and Minasny and Hartemink (2011) as the second group. However, the second group has better prediction results compared to the first group, in particular the prediction result of the PTF of Minasny and Hartemink (2011), which is confirmed by the statistical indices in Table 7.

According to Figure 3, the results of nine PTFs predicting SWR at $-33 \mathrm{kPa}$ show a large bias along the horizontal axis and, in particular the one by Aina and Periaswamy (1985) shows an extreme overestimation. These prediction biases are confirmed by the statistical indices in Table 7, where extreme biases are indicated by weak RMSE, EF and OF values while relatively low $\mathrm{ME}$ values are found due to a balance between overestimation and underestimation. Based on the indices in Table 7, the best PTF for SWR prediction at $-33 \mathrm{kPa}$ is the one developed by Pidgeon (1972), for the case of direct application in UBS

All selected point PTFs were used to predict SWR at $-1500 \mathrm{kPa}$. All prediction results show large biases along the horizontal axis (Figure 3). Nevertheless, the PTFs of Aina and Periaswamy (1985) and Lal (1979) have the best predictive power among the ten selected PTFs in Table 7. Finally, to select the most suitable PTF for direct application of SWR at $-1500 \mathrm{kPa}$, the OF values show that the PTFs of Aina and Periaswamy (1985) and Lal (1979) should be used.

The above variation of prediction performance most probably occurs because of the difference between predictors used in selected point PTFs, the applicability index and the geographical locations and conditions (which express soil conditions) where the calibration dataset was collected. Regarding the used predictors, this study highlights that some selected PTFs gave better results than other ones because they include the soil bulk density (BD) and/or organic content (OC) as predictors.

Table 6. Applicability index (\%) of PTFs against the upper Bengawan Solo soil dataset.

(A) Point PTF.

\begin{tabular}{|c|c|c|c|c|c|c|}
\hline \multirow{2}{*}{ Source } & \multirow{2}{*}{ Geographic domain } & \multirow{2}{*}{ Soil types } & \multicolumn{4}{|c|}{ Prediction for } \\
\hline & & & $\theta_{-10 \mathrm{kPa}}$ & & $\theta_{-33 k P a}$ & $\theta_{-1500 k P a}$ \\
\hline Pidgeon (1972) & Uganda & Ferralsols & 80 & & 80 & 80 \\
\hline Lal (1979) & Nigeria & Nitosols, Acrisols & 69 & & 69 & 69 \\
\hline Aina and Periaswamy (1985) & Western Nigeria & Nitosols, Acrisols & - & & 24 & 44 \\
\hline $\begin{array}{l}\text { Arruda et. al. (1987) in Tomasella } \\
\text { and Hodnett (2004) }\end{array}$ & South-East Brazil & Various & - & & 88 & 88 \\
\hline Dijkerman (1988) & Sierra Leone & Acrisols, Ferralsols, Cambisols & - & & 98 & 64 \\
\hline van den Berg et al. (1997) & Global & Ferralsols and related soils & 87 & & - & 88 \\
\hline $\begin{array}{l}\text { Oliveira et al. (2002) in } \\
\text { Tomasella and Hodnett (2004) }\end{array}$ & North-East Brazil & Various & - & & 96 & 74 \\
\hline Adhikary et al. (2008) & India & Various & 96 & & 96 & 87 \\
\hline Minasny and Hartemink (2011) & Tropical region (ISRIC database) & Various & 100 & & 100 & 100 \\
\hline Botula (2013) & Lower Congo & Highly weathered soils & - & & 66 & 66 \\
\hline \multicolumn{7}{|l|}{ (B) Continuous PTF } \\
\hline \multirow{2}{*}{ Source } & \multirow{2}{*}{ Geographic domain } & \multirow{2}{*}{ Soil types } & \multicolumn{4}{|c|}{ Prediction for vG parameter of } \\
\hline & & & $\theta_{r}$ & $\theta_{s}$ & $\alpha$ & $n$ \\
\hline van den Berg et al. (1997) & Global & Ferralsols and related soils & 61 & - & 88 & 61 \\
\hline Hodnett and Tomasella (2002) & $\begin{array}{l}\text { Tropical region (IGBP-DIS } \\
\text { database of ISRIC) }\end{array}$ & Nitosols, Acrisols & 89 & 83 & 83 & 83 \\
\hline
\end{tabular}


Application and recalibration of soil water retention pedotransfer functions in a tropical upstream catchment

Table 7. Statistical indices (ME, RMSE, EF, OF, r) for point PTFs in direct application against the upper Bengawan Solo soil dataset $(\mathrm{N}=94)$.

\begin{tabular}{|c|c|c|c|c|c|c|c|c|c|c|c|}
\hline & & \multicolumn{10}{|c|}{ Source } \\
\hline & & Pid & Lal & AP & $\mathrm{Ar}$ & Dij & $\mathrm{vdB}$ & Oli & Ad & MH & Bot \\
\hline \multirow{5}{*}{$\theta_{-10 k P a}$} & ME & -0.08 & -0.14 & - & - & - & -0.06 & - & 0.003 & 0.02 & - \\
\hline & RMSE & 0.13 & 0.17 & - & - & - & 0.10 & - & 0.12 & 0.07 & - \\
\hline & $\mathrm{EF}$ & -6.73 & -13.73 & - & - & - & -3.42 & - & -6.37 & -1.21 & - \\
\hline & OF & 7.73 & 14.73 & - & - & - & 4.42 & - & 7.37 & 2.21 & - \\
\hline & $\mathrm{r}$ & -0.05 & -0.12 & - & - & - & 0.17 & & 0.10 & 0.25 & - \\
\hline \multirow{5}{*}{$\theta_{-33 k P a}$} & ME & 0.01 & -0.02 & 0.27 & 0.06 & 0.02 & - & 0.01 & 0.05 & 0.10 & 0.08 \\
\hline & RMSE & 0.10 & 0.13 & 0.34 & 0.13 & 0.12 & - & 0.12 & 0.13 & 0.13 & 0.14 \\
\hline & $\mathrm{EF}$ & -6.40 & -11.96 & -83.25 & -10.76 & -9.44 & - & -10.35 & -11.85 & -11.02 & -14.56 \\
\hline & $\mathrm{OF}$ & 7.40 & 12.96 & 84.25 & 11.76 & 10.44 & - & 11.35 & 12.85 & 12.02 & 15.56 \\
\hline & $r$ & -0.30 & -0.31 & -0.31 & -0.38 & -0.34 & - & -0.33 & -0.21 & -0.14 & -0.36 \\
\hline \multirow{5}{*}{$\theta_{-1500 \mathrm{Ka}}$} & ME & 0.05 & -0.03 & -0.01 & 0.05 & 0.02 & 0.02 & 0.09 & 0.01 & 0.06 & 0.07 \\
\hline & RMSE & 0.11 & 0.09 & 0.09 & 0.09 & 0.11 & 0.09 & 0.13 & 0.10 & 0.10 & 0.13 \\
\hline & EF & -112.6 & -73.3 & -72.5 & -82.4 & -112.8 & -80.8 & -152.3 & -94.1 & -96 & -155.7 \\
\hline & $\mathrm{OF}$ & 113.6 & 74.30 & 73.50 & 83.40 & 113.8 & 81.80 & 153.3 & 95.10 & 97.00 & 156.7 \\
\hline & $\mathrm{r}$ & -0.12 & -0.16 & -0.17 & -0.18 & -0.16 & -0.16 & -0.22 & -0.09 & -0.06 & -0.21 \\
\hline \multirow{2}{*}{ Average } & $\mathrm{OF}$ & 42.91 & 34.00 & 52.58 & 31.72 & 41.41 & 28.74 & 54.88 & 38.44 & 37.08 & 57.42 \\
\hline & $\mathrm{r}$ & -0.16 & -0.20 & -0.24 & -0.28 & -0.25 & 0.00 & -0.28 & -0.07 & 0.02 & -0.28 \\
\hline
\end{tabular}

Pid: (Pidgeon, 1972); Lal: (Lal, 1979); AP: (Aina and Periaswamy, 1985); Ar: (Arruda et. al. (1987) in Tomasella and Hodnett (2004)); Dij: (Dijkerman, 1988); vdB: (van den Berg et al., 1997); Oli: (Oliveira et al. (2002) in Tomasella and Hodnett (2004)); Ad: (Adhikary et al., 2008); MH: (Minasny and Hartemink, 2011); Bot: (Botula, 2013).

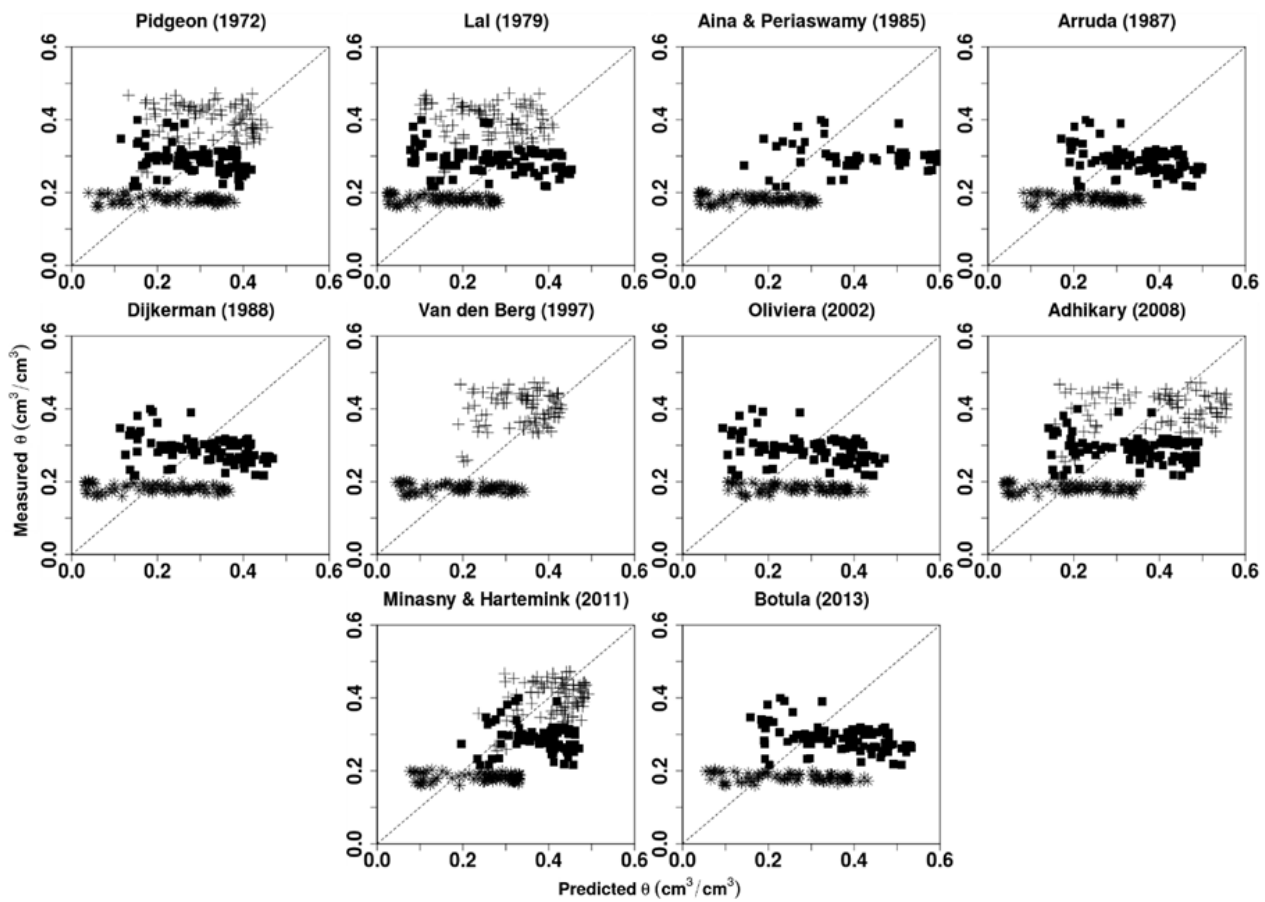

Fig. 3. Measured and predicted SWR by selected point PTFs at matric potentials of $-10 \mathrm{kPa}(+),-33 \mathrm{kPa}(\mathbf{\square})$ and $-1500 \mathrm{kPa}(*)$ for the case of UBS soil dataset $(\mathrm{N}=94)$.

This finding is partly in accordance with previous findings from a study of Pachepsky and Schaap (2004) which revealed that the structure of the soil pore space (which is commonly reflected by the soil bulk density and organic content) is closely related to the SWR at high matric potential (e.g. $-10 \mathrm{kPa}$ and $-33 \mathrm{kPa})$. Moreover, this finding is supported by the Pearson's correlation between these two soil properties of the UBS soil dataset in Table 2. An exception is the PTF of Aina and Periaswamy (1985) which includes BD as one of the predictors, but gives very poor predictions probably because of the low applicability index (Table 6). Selected point PTFs that have a high applicability index (Table 6) generally show better statistical indices compared to the performance of PTFs with a lower applicability index (Table 7). However, it does not mean that a high applicability index always results in the best prediction, because some point PTFs developed from local datasets show better predictions than ones based on a larger dataset (e.g., PTFs of Pidgeon (1972) and Aina and Periaswamy (1985) in predicting SWR at matric potential of $-33 \mathrm{kPa}$ and $-1500 \mathrm{kPa}$, respectively). This probably occurs because the geographical location and condition of the calibration dataset of those two PTFs have more similarity with UBS. In addition, previous studies of Manrique et al. (1991) and Minasny and Hartemink (2011) found that SWR at $-1500 \mathrm{kPa}$ is determined by the 
adsorption force of the soil matric (i.e. explained by soil texture distribution and clay mineral content) and this supports the most suitable prediction of the PTF developed by Aina and Periaswamy (1985) for the case of UBS. The findings are in accordance with the previous study of Tranter et al. (2009). They concluded that even though a PTF developed from an international dataset has a larger applicability index, it might be less precise than PTFs developed from local datasets which have similar soil conditions as the area where the PTF is validated.

The above evaluation and its comparison with previous studies of e.g. Tomasella and Hodnett (2004), Botula et al. (2012) and Nguyen et al. (2015) indicate that direct application of the selected point PTFs' in UBS is less successful. Alternative approaches for predicting SWR in UBS should be used, such as direct application of continuous PTFs, developing new PTFs with different methods (Minasny and Hartemink, 2011) or recalibrating existing point PTFs. However, for the sake of parsimony of PTF utilization in our study area, we only consider the first and third options which are discussed in the next sections.

\section{Continuous PTFs}

The performance of two selected continuous PTFs in estimating SWR at $0 \mathrm{kPa},-1 \mathrm{kPa},-10 \mathrm{kPa},-33 \mathrm{kPa}$ and $-1500 \mathrm{kPa}$ was evaluated by means of scatterplots in Figure 4 and statistical indices in Table 8.

Table 8. Statistical indices (ME, RMSE, EF, OF and r) for selected continuous PTFs in direct application against the upper Bengawan Solo soil dataset $(\mathrm{N}=94)$.

\begin{tabular}{|c|c|c|c|c|c|c|c|c|c|c|}
\hline & $\mathrm{ME}$ & RMSE & $\mathrm{EF}$ & OF & $\mathrm{r}$ & ME & RMSE & EF & OF & $\mathrm{r}$ \\
\hline \multicolumn{4}{|c|}{ van den Berg et al. (1997) } & \multicolumn{7}{|c|}{ Hodnett and Tomasella (2002) } \\
\hline$\theta_{0 k P a}$ & -0.001 & 0.05 & 0.353 & 0.6 & 0.6 & -0.007 & 0.04 & 0.51 & 0.49 & 0.73 \\
\hline$\theta_{-I k P a}$ & -0.01 & 0.06 & 0.004 & 1 & 0.38 & 0.011 & 0.04 & 0.43 & 0.57 & 0.69 \\
\hline$\theta_{-33 k P a}$ & -0.03 & 0.12 & -15.18 & 16.1 & -0.23 & 0.082 & 0.09 & -8.99 & 9.99 & 0.12 \\
\hline$\theta_{-1500 \mathrm{kPa}}$ & 0.005 & 0.11 & -109.1 & 110.1 & -0.1 & 0.082 & 0.09 & -92.61 & 93.61 & 0.03 \\
\hline Overall & -0.026 & 0.11 & 0.38 & 0.56 & 0.79 & 0.04 & 0.07 & 0.73 & 0.28 & 0.91 \\
\hline
\end{tabular}

Table 9. List of recalibrated PTFs.

\begin{tabular}{|c|c|}
\hline Source & Recalibrated PTFs \\
\hline Pidgeon (1972) & $\begin{array}{l}w_{-10 \mathrm{kPa}}(\%)=(7.70+0.07 \mathrm{Si}+0.03 \mathrm{Cl}+0.48 \mathrm{SOM}-2.35) 0.28^{-1} \\
w_{-33 \mathrm{kPa}}(\%)=(11.70+0.02 \mathrm{Si}+0.006 \mathrm{Cl}+0.6 \mathrm{SOM}-4.37) 0.36^{-1} \\
w_{-1500 \mathrm{kPa}}(\%)=13.47+0.03 \mathrm{Si}+0.01 \mathrm{Cl}+0.6 \mathrm{SOM}\end{array}$ \\
\hline Lal (1979) & $\begin{array}{l}w_{-10 k P a}(\mathrm{~g} / \mathrm{g})=0.327+0.0006 C l, w_{-33} \mathrm{kPa}(\mathrm{g} / \mathrm{g})=0.263+0.0001 C l \\
w_{-1500 \mathrm{kPa}}(\mathrm{g} / \mathrm{g})=0.16-0.000003 \mathrm{Cl}\end{array}$ \\
\hline Aina and Periaswamy (1985) & $w_{-33 k P a}(\%)=25.39+1.19 S a-1.03 B D S a, w_{-1500 k P a}(\%)=16.03-0.00028 C l$ \\
\hline $\begin{array}{l}\text { Arruda et. al. (1987) in Tomasella and } \\
\text { Hodnett (2004) }\end{array}$ & $w_{-33 k P a}(\%)=26.16-0.007(C l+S i), w_{-1500 k P a}(\%)=15.74+0.004(C l+S i)$ \\
\hline Dijkerman (1988) & $w_{-33 k P a}(\%)=25.43+0.007 S a, w_{-1500 k P a}(\%)=16.03-0.0003 C l$ \\
\hline van den Berg et al. (1997) & $\begin{array}{l}\theta_{-10 \mathrm{kPa}}(\%)=23.86+0.157 \mathrm{Cl}+0.33 \mathrm{Si}+1.1560 \mathrm{C} \\
\theta_{-1500 \mathrm{kPa}}(\%)=(0.099 \mathrm{Cl}+0.411 \mathrm{Si}) \mathrm{BD}\end{array}$ \\
\hline van den Berg et al. (1997)* & $\begin{array}{l}\theta_{r}(\%)=0.251 C l B D, \ln \alpha\left(\mathrm{kPa}^{-1}\right)=-1.201 \\
\theta_{s}(\%)=88.4-0.327 C l B D-0.297(S a+S i) B D \\
m=0.205-(0.0023(S i+C l)+0.032 O C-0.0032 C E C) B D\end{array}$ \\
\hline Hodnett and Tomasella (2002)* & $\begin{array}{l}\theta_{r}(\%)=28.057-0.091 S a+0.2 C E C-3.237 p H+0.0004 C l^{2}+0.0064 S a C l \\
\theta_{S}(\%)=86.314-0.018 C l-33.930 B D-0.209 C E C+1.326 p H+0.0024 S a C l \\
\ln \alpha\left(x 100 \mathrm{kPa}^{-1}\right)=35.49-3.8556 S i+3.280 O C+0.422 C E C-6.844 p H+0.073 S i^{2} \\
\ln n(x 100)=62.986-0.883 C l-0.529 O C+0.593 p H+0.007 C l^{2}-0.014 S a S i\end{array}$ \\
\hline $\begin{array}{l}\text { Oliveira et al. (2002) in Tomasella and } \\
\text { Hodnett (2004) }\end{array}$ & $\begin{array}{l}w_{-33 k P a}\left(\mathrm{~kg} \mathrm{~kg}^{-1}\right)=0.00677 S i+0.00148 C l \\
w_{-1500 \mathrm{kPa}}\left(\mathrm{kg} \cdot \mathrm{kg}^{-1}\right)=0.00334 S a+0.003938 \mathrm{Si}+0.003491 \mathrm{Cl}-0.17146 B D\end{array}$ \\
\hline Adhikary et al. (2008) & $\begin{array}{l}\theta_{-10 \mathrm{kPa}}(\%)=39.5-0.14 \mathrm{Sa}+0.20 \mathrm{Si}, \theta_{-33 \mathrm{kPa}}(\%)=26.99-0.006 \mathrm{Sa}+0.09 \mathrm{Si} \\
\theta_{-1500 \mathrm{kPa}}(\%)=18.03+0.0059 \mathrm{Cl}\end{array}$ \\
\hline Minasny and Hartemink (2011) & $\begin{array}{l}\theta_{-10 \mathrm{kPa}}(\%)=58.35-12.17 \mathrm{BD}-0.13 \mathrm{Sa} \\
\theta_{-33 \mathrm{kPa}}(\%)=47.9-16.22 \mathrm{BD}-0.007 \mathrm{Sa} \\
\theta_{-1500 \mathrm{kPa}}(\%)=17.74+0.220 \mathrm{C}+0.02 \mathrm{Cl}-0.0006(\mathrm{Cl}-34.2)^{2}\end{array}$ \\
\hline Botula et al. (2012) & $\begin{array}{l}w_{-33 k P a}\left(\mathrm{~g} \cdot \mathrm{g}^{-1}\right)=0.2576+0.0002 S a \\
w_{-1500 k P a}\left(\mathrm{~g} \cdot \mathrm{g}^{-1}\right)=0.4-0.00056 S a-0.0004 C l-0.1787 B D\end{array}$ \\
\hline
\end{tabular}

*continuous PTF; $w_{-10 \mathrm{kPa}}, w_{-33 \mathrm{kPa}}, w_{-1500 \mathrm{kPa}}$ and $\theta_{-10 \mathrm{kPa}}, \theta_{-33 \mathrm{kPa}}, \theta_{-1500 \mathrm{kPa}}$ : gravimetric and volumetric SWR at matric potential of $-10 \mathrm{kPa},-33 \mathrm{kPa}$ and $-1500 \mathrm{kPa}$, respectively; Sa, Si, Cl, OC: sand, silt, clay, organic carbon content in $\mathrm{g} \mathrm{g}^{-1} \times 100$; SOM: soil organic matter = $1.724 \mathrm{OC}$, in $\mathrm{g} \mathrm{g}^{-1}$ x 100; BD: soil bulk density in $\mathrm{g} \mathrm{cm}^{-3}$, CEC: cation exchange capacity in $\mathrm{cmol} \mathrm{kg}^{-1}$; $\mathrm{pH}$ : soil acidity (unit less). 


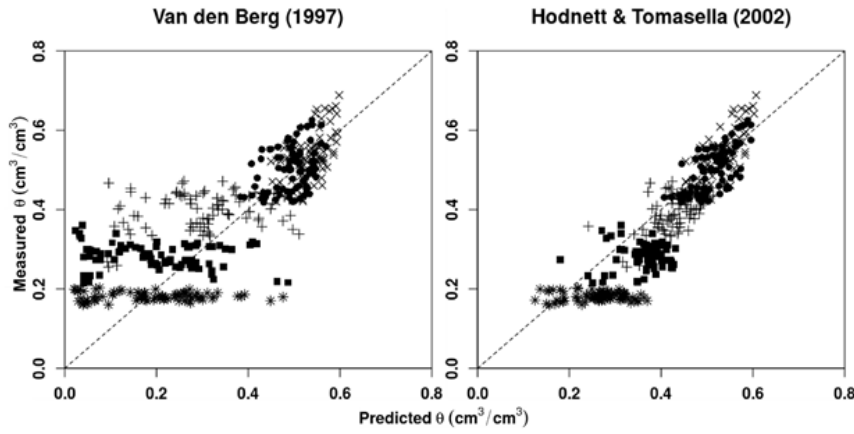

Fig. 4. Measured and predicted SWR by selected continuous PTFs at matric potentials of $0 \mathrm{kPa}(7),-1 \mathrm{kPa}(+),-10 \mathrm{kPa}(+)$, $-33 \mathrm{kPa}(\mathbf{-})$ and $-1500 \mathrm{kPa}\left(^{*}\right)$ for the case of UBS soil dataset $(\mathrm{N}=94)$.

In direct application, both selected continuous PTFs tend to underestimate and overestimate the measured SWR unevenly at the five measurement points. However, regarding the overall prediction error by means of RMSE, the prediction results of the PTF developed by Hodnett and Tomasella (2002) are superior to the PTF developed by van den Berg et al. (1997). The same superiority is also found for the model efficiency by means of EF. Therefore, the PTF developed by Hodnett and Tomasella (2002) can be proposed for SWR prediction in the upper Bengawan Solo.

After all, both continuous PTFs for SWR prediction at specific points, in particular for matric potentials of $-10 \mathrm{kPa}$, $-33 \mathrm{kPa}$ and $-1500 \mathrm{kPa}$, do not show significantly different results than the best performing point PTFs in the previous section.However, when considering the continuous PTF of Hodnett and Tomasella (2002) for predicting the whole soilwater retention curve, the results of its direct application by means of overall performance indicators seems to indicate that the PTF is suitable to be applied in UBS. In addition, a comparison of the ME and RMSE with the results of previous studies of Wösten et al. (2013) (overall ME and RMSE of $0.017 \mathrm{~cm}^{3} \mathrm{~cm}^{-3}$ and $0.064 \mathrm{~cm}^{3} \mathrm{~cm}^{-3}$, respectively) and Hodnett and Tomasella (2002) (overall RMSE of $0.049 \mathrm{~cm}^{3} \mathrm{~cm}^{-3}$ ) support the above PTF suitability conclusion.

A

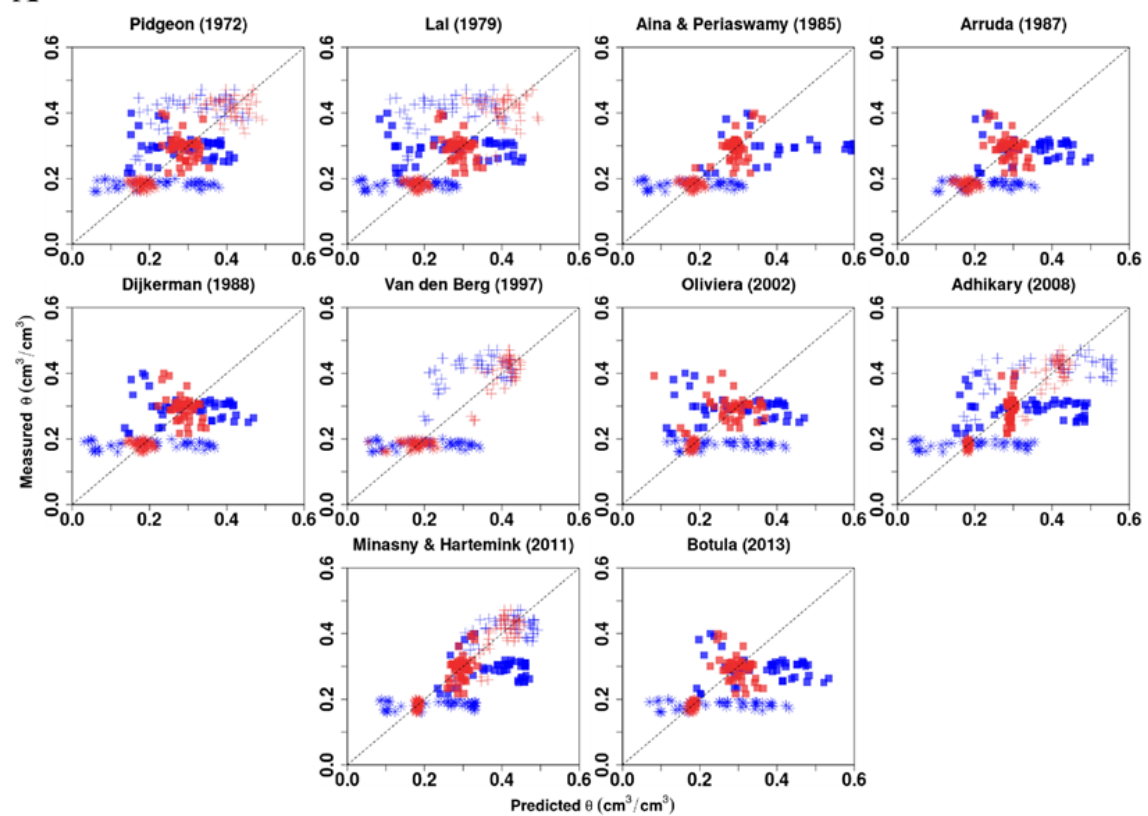

B

Van den Berg (1997)

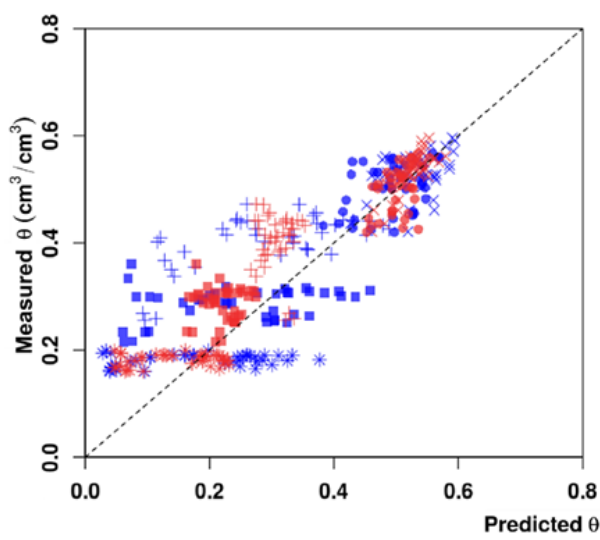

Hodnett \& Tomasella (2002)

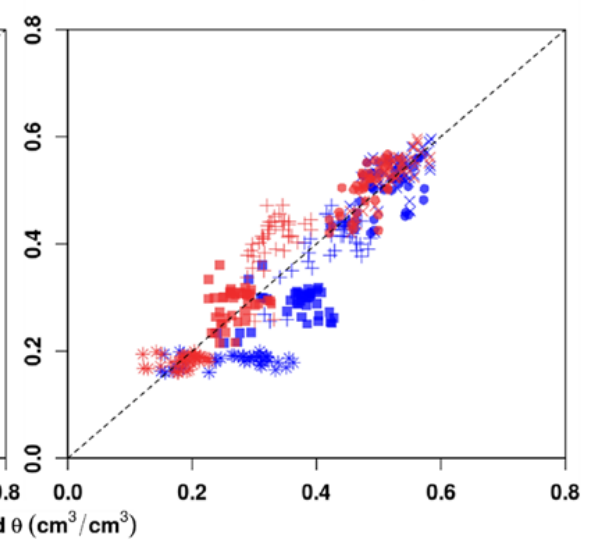

Fig. 5. Measured and predicted SWR by original (in blue colour) and recalibrated (in red colour) selected point PTFs (A) and continuous PTFs (B) at matric potentials of $0 \mathrm{kPa}(7),-1 \mathrm{kPa}(+),-10 \mathrm{kPa}(+),-33 \mathrm{kPa}(\mathbf{-})$ and $-1500 \mathrm{kPa}(*)$ for the upper Bengawan Solo recalibration soil dataset $(\mathrm{N}=47)$. 
Table 10. Prediction performance of recalibrated PTFs against calibration dataset (accuracy) by means of statistical indices ME, RMSE, $\mathrm{EF}, \mathrm{OF}$ and $\mathrm{r}$.

(A) The recalibrated point PTFs $(\mathrm{N}=47)$.

\begin{tabular}{|c|c|c|c|c|c|c|c|c|c|c|c|}
\hline & \multicolumn{10}{|c|}{ Source } \\
\hline & & Pid & Lal & AP & $\mathrm{Ar}$ & Dij & $\mathrm{vdB}$ & Oli & Ad & $\mathrm{MH}$ & Bot \\
\hline \multirow{5}{*}{$\theta_{-10 k P a}$} & ME & -0.004 & -0.005 & - & - & - & 0.0006 & - & 0.0001 & 0.0001 & - \\
\hline & RMSE & 0.06 & 0.07 & - & - & - & 0.04 & - & 0.04 & 0.04 & - \\
\hline & $\mathrm{EF}$ & -0.45 & -0.85 & - & - & - & 0.43 & - & 0.41 & 0.39 & - \\
\hline & OF & 1.45 & 1.85 & - & - & - & 0.57 & - & 0.59 & 0.61 & - \\
\hline & $\mathrm{r}$ & 0.28 & 0.00 & - & - & - & 0.66 & - & 0.64 & 0.62 & - \\
\hline \multirow{5}{*}{$\theta_{-33 k P a}$} & $\mathrm{ME}$ & -0.004 & -0.004 & -0.0008 & -0.004 & -0.004 & - & -0.0123 & -0.0003 & 0.0001 & -0.0048 \\
\hline & RMSE & 0.05 & 0.06 & 0.04 & 0.06 & 0.06 & - & 0.07 & 0.04 & 0.03 & 0.06 \\
\hline & $\mathrm{EF}$ & -0.85 & -1.17 & 0.15 & -1.18 & -1.18 & - & -2.42 & 0.04 & 0.20 & -1.24 \\
\hline & OF & 1.85 & 2.17 & 0.85 & 2.18 & 2.18 & - & 3.42 & 0.96 & 0.80 & 2.24 \\
\hline & $\mathrm{r}$ & -0.20 & -0.45 & 0.45 & -0.45 & -0.45 & - & -0.05 & 0.19 & 0.45 & -0.46 \\
\hline \multirow{5}{*}{$\theta_{-1500 \mathrm{kPa}}$} & $\mathrm{ME}$ & -0.002 & -0.002 & -0.002 & -0.002 & -0.002 & -0.007 & -0.0004 & -0.0002 & 0.0001 & -0.0001 \\
\hline & RMSE & 0.02 & 0.02 & 0.02 & 0.02 & 0.02 & 0.04 & 0.01 & 0.01 & 0.01 & 0.01 \\
\hline & $\mathrm{EF}$ & -3.13 & -3.71 & -3.71 & -3.7 & -3.71 & -10.56 & 0.15 & 0.02 & 0.10 & 0.14 \\
\hline & OF & 4.13 & 4.71 & 4.71 & 4.70 & 4.71 & 11.56 & 0.85 & 0.98 & 0.90 & 0.86 \\
\hline & $\mathrm{r}$ & -0.20 & -0.28 & -0.28 & -0.27 & -0.28 & 0.20 & 0.41 & 0.14 & 0.32 & 0.40 \\
\hline \multirow{2}{*}{ Average } & OF & 2.48 & 2.91 & 1.85 & 2.29 & 2.30 & 4.04 & 1.42 & 0.84 & 0.77 & 1.03 \\
\hline & $\mathrm{r}$ & -0.04 & -0.24 & 0.08 & -0.36 & -0.37 & 0.43 & 0.18 & 0.32 & 0.46 & -0.03 \\
\hline
\end{tabular}

(B) The recalibrated continuous PTFs $(\mathrm{N}=47)$.

\begin{tabular}{|c|c|c|c|c|c|c|c|c|c|c|}
\hline & $\mathrm{ME}$ & RMSE & $\mathrm{EF}$ & $\mathrm{OF}$ & $\mathrm{r}$ & $\mathrm{ME}$ & RMSE & EF & $\mathrm{OF}$ & $\mathrm{r}$ \\
\hline \multicolumn{6}{|c|}{ van den Berg et al. (1997) } & \multicolumn{5}{|c|}{ Hodnett and Tomasella (2002) } \\
\hline$\theta_{0 k P a}$ & -0.006 & 0.03 & 0.58 & 0.42 & 0.78 & 0.001 & 0.03 & 0.85 & 0.15 & 0.86 \\
\hline$\theta_{-I k P a}$ & 0.003 & 0.04 & 0.23 & 0.77 & 0.49 & -0.021 & 0.04 & 0.68 & 0.32 & 0.69 \\
\hline$\theta_{-10 \mathrm{kPa}}$ & -0.095 & 0.11 & -3.7 & 4.70 & -0.04 & -0.073 & 0.09 & -1.8 & 2.80 & 0.50 \\
\hline$\theta_{-33 k P a}$ & -0.066 & 0.08 & -5.1 & 6.10 & 0.04 & -0.017 & 0.04 & -0.63 & 1.63 & 0.21 \\
\hline$\theta_{-1500 \mathrm{kPa}}$ & -0.037 & 0.07 & -44.8 & 45.8 & 0.19 & 0.005 & 0.03 & -4.9 & 5.90 & 0.23 \\
\hline Overall & -0.040 & 0.07 & 0.72 & 0.29 & 0.92 & -0.022 & 0.05 & 0.88 & 0.13 & 0.95 \\
\hline
\end{tabular}

Pid: (Pidgeon, 1972); Lal: (Lal, 1979); AP: (Aina and Periaswamy, 1985); Ar: (Arruda et. al. (1987) in Tomasella and Hodnett (2004)); Dij: (Dijkerman, 1988); vdB: (van den Berg et al., 1997); Oli: (Oliveira et al. (2002) in Tomasella and Hodnett (2004)); Ad: (Adhikary et al., 2008); MH: (Minasny and Hartemink, 2011); Bot: (Botula, 2013).

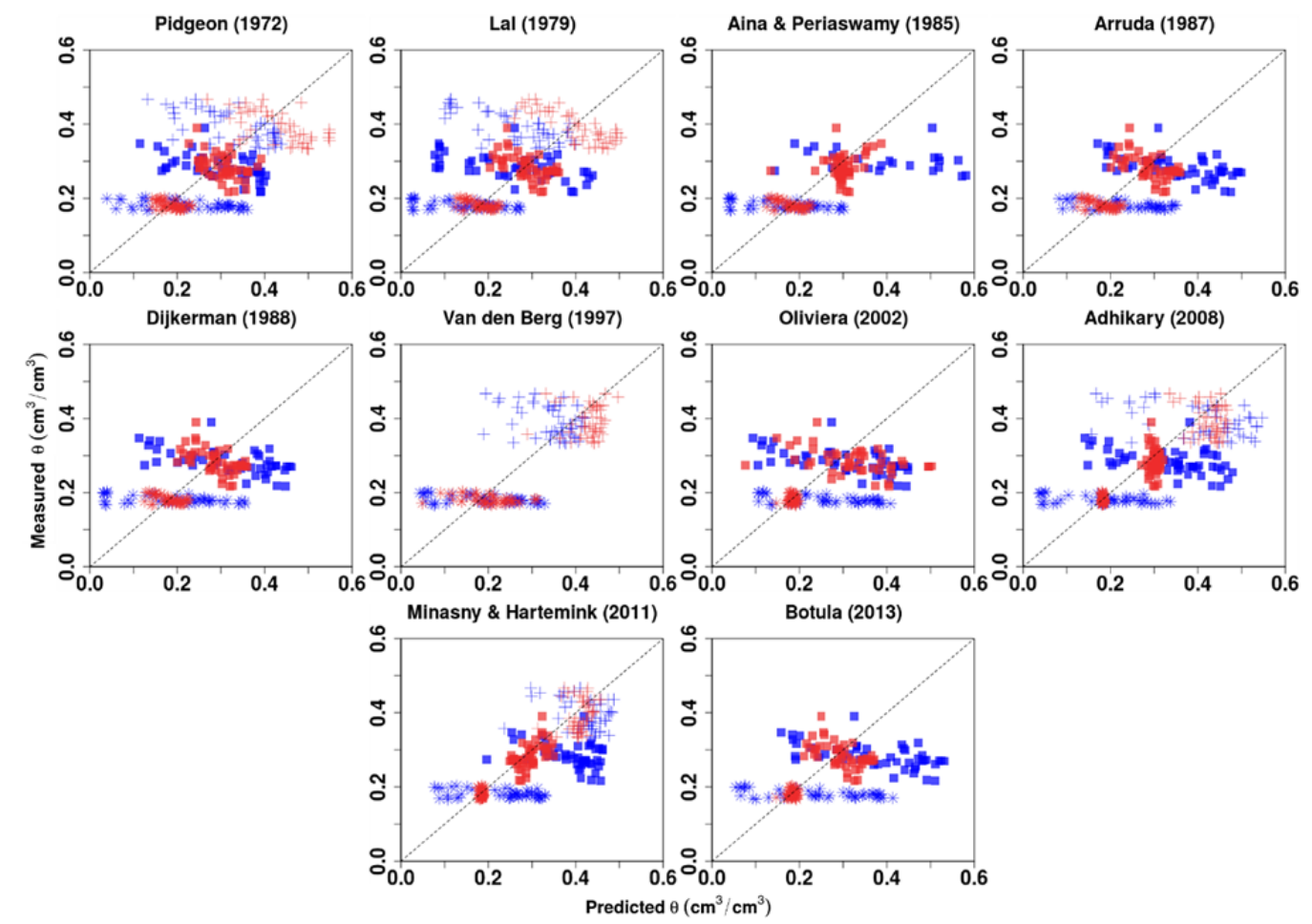

Fig. 6. Measured and predicted SWR by original (in blue colour) and recalibrated (in red colour) selected point PTFs at matric potentials of $-10 \mathrm{kPa}(+),-33 \mathrm{kPa}(\mathbf{\square})$, and $-1500 \mathrm{kPa}(*)$ for the case of $\mathrm{UBS}$ validation soil dataset $(\mathrm{N}=47)$. 


\section{Recalibration of selected PTFs}

The twelve selected PTFs have been recalibrated against the UBS soil dataset using the SCE-UA algorithm and the results are presented in Table 9.

The performance of the recalibrated point PTFs against their own recalibration datasets (known as accuracy according to Wösten et al. (2001), where the predicted SWR from the recalibrated PTF is evaluated using the measured SWR from the recalibration dataset) was better as compared to the results of the un-recalibrated PTFs (Figure 5A). Furthermore, the ME and RMSE values in Table 10A show a reasonable prediction of SWR at matric potentials of $-10 \mathrm{kPa},-33 \mathrm{kPa}$ and $-1500 \mathrm{kPa}$.

In particular, RMSE values in Table 10A are comparable to those obtained by Wösten et al. (2001), which are considered to be a benchmark for accuracy assessment of PTF prediction, the values are comparable and show good results. Considering EF, $\mathrm{OF}$ and $\mathrm{r}$ values in Table 10A, reasonable results of recalibrated PTFs for predicting SWR of $-10 \mathrm{kPa},-33 \mathrm{kPa}$ and $-1500 \mathrm{kPa}$ are mostly only obtained by PTFs that were originally developed from international and large soil datasets.
For the case of continuous PTFs, Figure 5b shows that the recalibration has improved the performance in general, particularly at low matric potentials $(-33 \mathrm{kPa}$ and $-1500 \mathrm{kPa})$. Although the ME and RMSE values show that the prediction results seem reasonable, the EF values at matric potentials of $-10 \mathrm{kPa}$, $-33 \mathrm{kPa}$ and $-1500 \mathrm{kPa}$ point towards an opposite conclusion. To sum up, the performance of the recalibrated continuous PTFs originally developed by Hodnett and Tomasella (2002) is superior to the one of van den Berg et al. (1997) for all five matric potentials. The performance of the recalibrated PTFs is comprehensively discussed in the next section using an independent (validation) dataset.

\section{Validation of recalibrated selected PTFs Point PTFS}

The recalibrated point PTFs have been validated against the UBS validation soil dataset and compared with the results of the direct application, presented in Figure 6 and Table 11.

Figure 6 shows that the prediction results of the recalibrated point PTFs have almost the same pattern as the ones in the

Table 11. Prediction performance by means of statistical indices ME, RMSE, EF, OF and $r$ of the original and recalibrated point PTFs against the upper Bengawan Solo validation soil dataset $(\mathrm{N}=47)$.

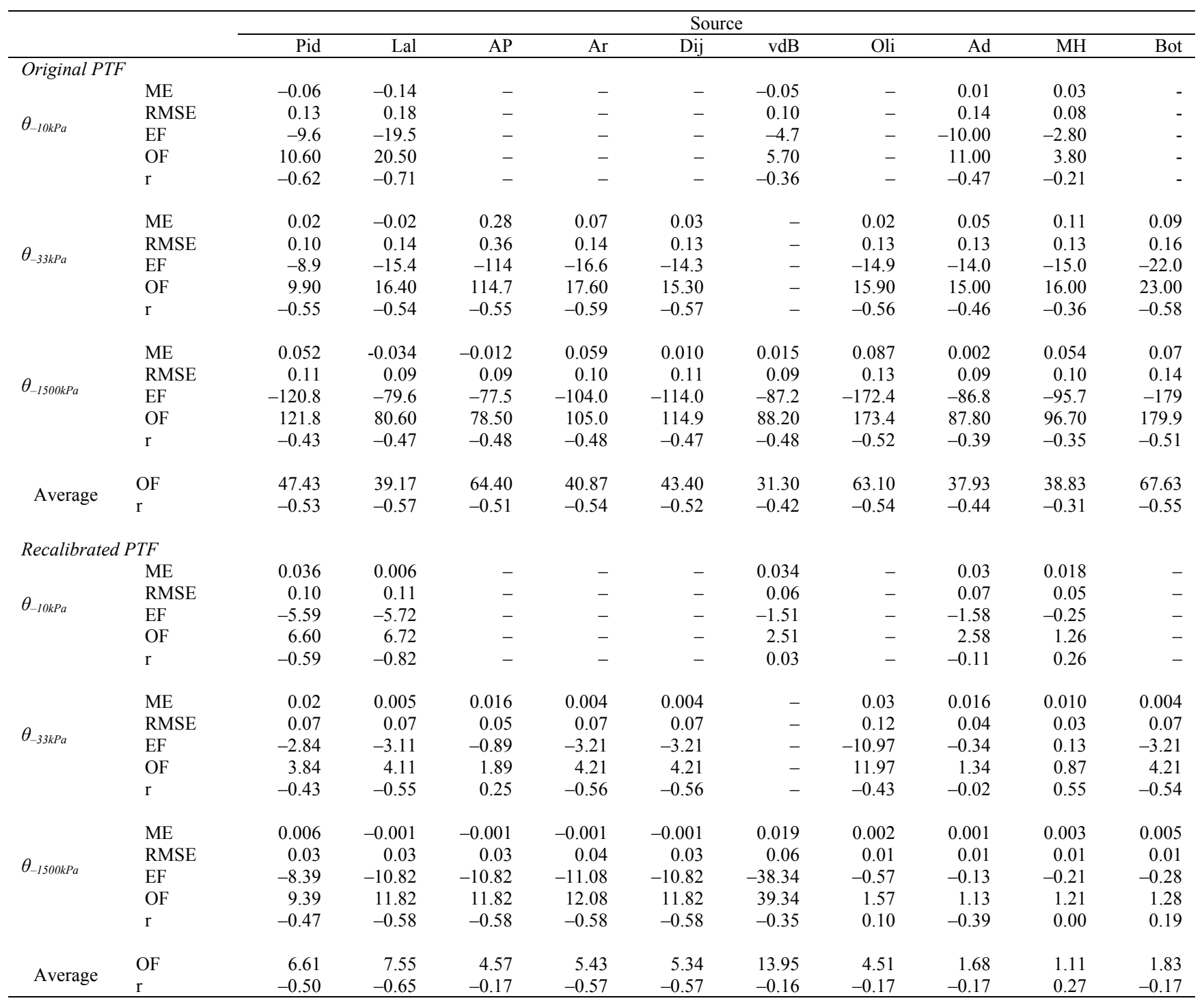

Pid: (Pidgeon, 1972); Lal: (Lal, 1979); AP: (Aina and Periaswamy, 1985); Ar: (Arruda et. al. (1987) in Tomasella and Hodnett (2004)); Dij: (Dijkerman, 1988); vdB: (van den Berg et al., 1997); Oli: (Oliveira et al. (2002) in Tomasella and Hodnett (2004)); Ad: (Adhikary et al., 2008); MH: (Minasny and Hartemink, 2011); Bot: (Botula, 2013) 
Table 12. Prediction performance by means of statistical indices ME, RMSE, EF, OF and $r$ of the original and recalibrated continuous PTFs against the upper Bengawan Solo validation soil dataset $(N=47)$.

\begin{tabular}{|c|c|c|c|c|c|c|c|c|c|c|}
\hline & \multicolumn{4}{|c|}{ Original PTF } & & \multicolumn{5}{|c|}{ Recalibrated PTF } \\
\hline & $\mathrm{ME}$ & RMSE & $\mathrm{EF}$ & $\mathrm{OF}$ & $\mathrm{r}$ & $\mathrm{ME}$ & RMSE & EF & $\mathrm{OF}$ & $\mathrm{r}$ \\
\hline & \multicolumn{10}{|c|}{ van den Berg et al. (1997) } \\
\hline$\theta_{0 k P a}$ & -0.002 & 0.06 & 0.49 & 0.51 & 0.73 & -0.0002 & 0.03 & 0.86 & 0.14 & 0.83 \\
\hline$\theta_{-10 k P a}$ & -0.080 & 0.14 & -11.6 & 12.6 & -0.27 & -0.0716 & 0.08 & -3.2 & 4.20 & 0.43 \\
\hline$\theta_{-33 k P a}$ & -0.019 & 0.13 & -17.3 & 18.3 & -0.50 & -0.0519 & 0.07 & -4.4 & 5.40 & -0.10 \\
\hline$\theta_{-1500 \mathrm{kPa}}$ & 0.009 & 0.12 & -135.2 & 136.2 & -0.27 & -0.0401 & 0.07 & -42.4 & 43.40 & -0.39 \\
\hline Overall & \multicolumn{10}{|c|}{ Hodnett and Tomasella (2002) } \\
\hline$\theta_{0 k P a}$ & -0.008 & 0.05 & 0.61 & 0.39 & 0.95 & 0.001 & 0.03 & 0.85 & 0.15 & 0.94 \\
\hline$\theta_{-l k P a}$ & 0.010 & 0.04 & 0.57 & 0.43 & 0.93 & -0.021 & 0.04 & 0.68 & 0.32 & 0.89 \\
\hline$\theta_{-10 k P a}$ & 0.042 & 0.06 & -1.4 & 2.40 & 0.67 & -0.060 & 0.07 & -2.4 & 3.40 & 0.31 \\
\hline$\theta_{-33 k P a}$ & 0.086 & 0.10 & -10.7 & 11.7 & 0.30 & -0.012 & 0.04 & -1.1 & 2.10 & 0.00 \\
\hline$\theta_{-1500 k P a}$ & 0.079 & 0.10 & -93.8 & 94.8 & -0.21 & 0.004 & 0.03 & -8.7 & 9.70 & -0.32 \\
\hline Overall & 0.042 & 0.07 & 0.72 & 0.29 & 0.95 & -0.017 & 0.05 & 0.90 & 0.11 & 0.95 \\
\hline
\end{tabular}

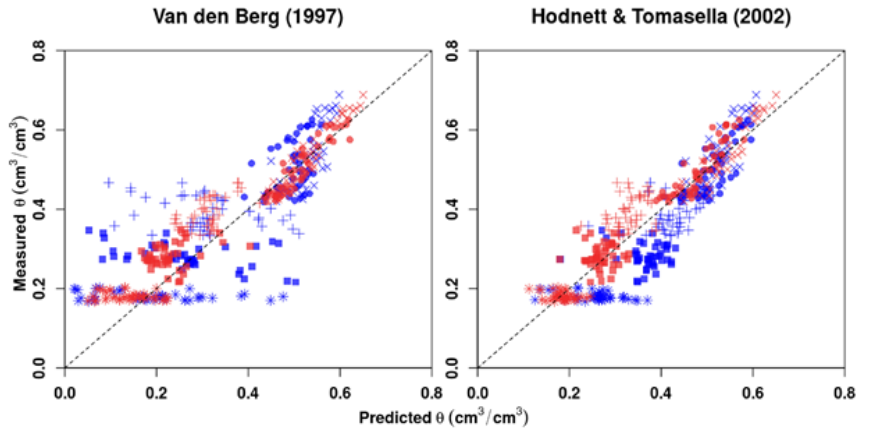

Fig. 7. Measured and predicted SWR by original (in blue colour) and recalibrated (in red colour) selected point PTFs at matric potentials of $0 \mathrm{kPa}(7),-1 \mathrm{kPa}(+),-10 \mathrm{kPa}(+),-33 \mathrm{kPa}(\mathbf{\square})$, and $-1500 \mathrm{kPa}\left({ }^{*}\right)$ for the upper Bengawan Solo validation soil dataset $(\mathrm{N}=47)$.

accuracy assessment (Figure 5A). In general, the large scatter on the left and right hand side of 1:1 line is reduced. In addition to Figure 6, the results in Table 11 indicate an improvement of prediction of the recalibrated point PTFs compared with the original un-recalibrated ones. The ME and RMSE are relatively small to moderate for the prediction results of most recalibrated point PTFs. For the EF value, significant improvements of the prediction of SWR at $-10 \mathrm{kPa},-33 \mathrm{kPa}$ and $-1500 \mathrm{kPa}$ are shown by the recalibrated PTFs compared with the results of the un-recalibrated ones. Nevertheless, for prediction of SWR at $-33 \mathrm{kPa}$, only the recalibrated version of the PTF developed by Minasny and Hartemink (2011) yielded positive values of EF, while the other PTFs show opposite results (Table 11). A previous study of Fila et al. (2006) also obtained a negative EF value in their PTF evaluation which was still considered to be a favourable prediction provided the negative EF value was not too low $(-0.677)$ and other PTF evaluators (RMSE and r) showed a good or reasonable results. In conclusion, the best prediction results of SWR at matric potentials of $-10 \mathrm{kPa}$, $-33 \mathrm{kPa}$ and $-1500 \mathrm{kPa}$ for the case of recalibrated point PTFs are obtained by PTFs that were originally developed by Minasny and Hartemink (2011). This is a recalibrated point PTF with a high applicability index (Table 6), uses predictors that are significantly correlated to a particular SWR (Table 2) and is the most suitable one for application in a tropical upstream catchment such as UBS to fill the gap of SWR data.

\section{Continuous PTFs}

A comparison of SWR at $0 \mathrm{kPa},-1 \mathrm{kPa},-10 \mathrm{kPa},-33 \mathrm{kPa}$ and $-1500 \mathrm{kPa}$ predicted by recalibrated and original selected continuous PTFs is presented in Figure 7. A significant improvement is shown in the figure for both PTFs, except for the recalibrated PTF of Hodnett and Tomasella (2002) when predicting SWR at $-10 \mathrm{kPa}$.

Confirming Figure 7, the list of statistical indices in Table 12 shows an improvement in results between the original and recalibrated continuous PTFs. ME and RMSE values for both recalibrated continuous PTFs indicate that the obtained SWR predictions are reasonable at all measured soil-water matric potentials. However, the EF values still show the same pattern as the prediction results before recalibration, where reliable results are only obtained for SWR prediction at high matric potentials of $0 \mathrm{kPa}$ and $-1 \mathrm{kPa}$. The unreliable results of SWR at $-10 \mathrm{kPa},-33 \mathrm{kPa}$ and $-1500 \mathrm{kPa}$ for the continuous PTFs most probably could be explained by the shape parameters $(m$ and $n$ ) and the scale parameter $(\alpha)$ of the vG soil-water release curve model. The parameters $m$ and $n$ and $\alpha$ actually have no clear physical meaning, they must be determined empirically by curve fitting to the measured SWR data solely (van den Berg et al., 1997). However, those two parameters have a low fitting quality during the PTF development (van den Berg et al., 1997; Hodnett and Tomasella, 2002). Some reasons for this poor fitting are SWR measurement errors and the number of points that was used to define the water-release curve (Tomasella et al., 2000). Since the soil dataset of UBS only covers SWR at five matric potentials, the recalibration of both PTFs could not significantly improve the shape parameters of the vG model. In addition, the lack of measured CEC as one of the predictors of the curve shape parameter can contribute to the poor prediction.

When considering the EF, ME and RMSE values, the prediction of both PTFs, in particular at high matric potentials (i.e., less negative), seems reliable. This is supported by $r$ values which indicate a positive correlation between predicted and measured water retention curves for the case of UBS. This result is comparable with results of previous studies (e.g. Tomasella and Hodnett, 1998; Wösten et al., 2013). For PTF application in UBS, both PTFs can be used to reasonably predict soil-water release, in particular the one originally developed by Hodnett and Tomasella (2002). 


\section{CONCLUSIONS}

This study has selected and evaluated ten point PTFs and two continuous PTFs that were developed based on soil datasets from tropical regions for an application in the upper Bengawan Solo catchment. When selected point PTFs were used for direct application against the UBS soil dataset, a low performance was shown by part of the point PTFs in predicting SWR at $-10 \mathrm{kPa}$, while none of the point PTFs are suitable to predict SWR at $-33 \mathrm{kPa}$ and $-1500 \mathrm{kPa}$. Similar results were obtained with the selected continuous PTFs, however, when predicting the whole soil-water retention curve, one PTF gave a reasonable result. Instead of developing new PTFs, for the sake of parsimony, recalibration of the PTFs was done successfully to improve the prediction results compared to direct application. Most of the recalibrated PTFs in this study resulted in reasonable predictions according to the evaluation criteria $\mathrm{ME}$ and RMSE, which have been the commonly used criteria in previous PTF evaluation studies. Even though EF indicated that the selected PTFs gave unreliable prediction results, it shows at least a significant improvement through recalibration compared to the results of un-recalibrated PTFs.

The improvement of the predictions of selected PTFs after recalibration means that there are more options for suitable PTFs that can be applied in UBS, however the final selection should be dependent on the kind of application. For applications that only require SWR at field capacity $(-10 \mathrm{kPa}$ or $-33 \mathrm{kPa})$ and permanent wilting point $(-1500 \mathrm{kPa})$, the use of the most suitable recalibrated point PTFs is recommended for the sake of parsimony and also because the predictions of recalibrated continuous PTFs are less successful compared with the point PTFs. However, for applications that require a complete soil-water release curve, the most reasonable recalibrated continuous PTF should be used in UBS, also taking into account previous evaluation studies. Further application of recalibrated PTFs beyond UBS should be done with care given the results of this study.

Acknowledgements. This research was conducted with the support of a DIKTI scholarship from the Ministry of Higher Education and Research of the Republic of Indonesia. We would like to thank and acknowledge in particular: (1) Sigit Haryadi, Agung, Janni, Kumala and other staff from the River Management Office of Solo; (2) Oka Karyanto and Makruf Nurudin from Gadjah Mada University in Yogyakarta; (3) Djoko Harmantyo, Awal Setiawan, Roland Sinulingga and Kuswantoro from the University of Indonesia and; (4) Yuli Priana from Muhammadiyah University of Surakarta, for their help and assistance; (5) The editor and both reviewers for their constructive comments.

\section{REFERENCES}

Abdelbaki, A.M., 2015. Using automatic calibration method for optimizing the performance of Pedotransfer functions of saturated hydraulic conductivity. Ain Shams Engineering Journal, 7, 2, 653-662.

Adhikary, P.P., Chakraborty, D., Kalra, N., Sehgal, M., 2008. Pedotransfer functions for predicting the hydraulic properties of Indian soils. Australian Journal of Soil Research, 46, 5, 476.

Aina, P.O., Periaswamy, S.P., 1985. Estimating available water-holding capacity of western nigerian soils from soil texture and bulk density, using core and sieved samples. Soil Science, 140, 1, 55-58.
Bell, M.A., van Keulen, H., 1995. Soil Pedotransfer Functions for Four Mexican Soils. Soil Science Society of America Journal, 59, 3, 865.

Beretta, A.N., Silbermann, A.V., Paladino, L., Torres, D., Bassahun, D., Musselli, R., García-Lamohte, A., 2014. Soil texture analyses using a hydrometer: modification of the Bouyoucos method. Ciencia e Investigación Agraria, 41, 2, 263-271.

Bittelli, M., Flury, M., 2009. Errors in water retention curves determined with pressure plates. Soil Science Society of America Journal, 73, 5, 1453.

Blasone, R.S., Madsen, H., Rosbjerg, D., 2006. Comparison of parameter estimation algorithm in hydrological modelling. In: Proceedings of ModelCARE'2005. IAHS Press, Wallingford, p. 67-72.

Botula, Y.D., 2013. Indirect Methods to Predict Hydrophysical Properties of Soils of Lower Congo. Ghent University, Ghent, $236 \mathrm{p}$.

Botula, Y.D., Cornelis, W.M., Baert, G., Van Ranst, E., 2012. Evaluation of pedotransfer functions for predicting water retention of soils in Lower Congo (D.R. Congo). Agricultural Water Management, 111, 1-10.

Bouma, J., 1989. Using soil survey data for quantitative land evaluation. In: Advances in Soil Science. Springer, New York, pp. 177-213.

Dijkerman, J.C., 1988. An Ustult-Aquult-Tropept catena in Sierra Leone, West Africa, II. Land qualities and land evaluation. Geoderma, 42, 1, 29-49.

Duan, Q., Sorooshian, S., Gupta, V.K., 1994. Optimal use of the SCE-UA global optimization method for calibrating watershed models. Journal of Hydrology, 158, 3-4, 265284.

Durner, W., Lipsius, K., 2006. Determining Soil Hydraulic Properties. In: Encyclopedia of Hydrological Sciences. John Wiley \& Sons.

Feddes, R.A., de Rooij, G.H., van Dam J.C. (Eds.), 2004. Unsaturated-Zone Modeling: Progress, Challenges and Applications. Kluwer Acad. Publ., 364 p.

Fila, G., Donatelli, M., Bellocchi, G., 2006. PTFIndicator: An IRENE DLL-based application to evaluate estimates from pedotransfer functions by integrated indices. Environmental Modelling \& Software, 21, 1, 107-110.

Gee, G.W., Bauder, J.W., 1986. Particle-size analysis. In: Klute, A. (Ed.): Methods of Soil Analysis. Part 1: Physical and Mineralogical Methods. Soil Science Society of America, American Society of Agronomy, Madison, WI, pp. 383-411.

Grossman, R.B., Reinsch, T.G., 2002. The solid phase. In: Dane, J.H., Topp, C.G. (Eds.): Methods of Soil Analysis. Part 4: Physical Methods. Soil Science Society of America, American Society of Agronomy, Madison, WI, pp. 201-228.

Hartemink, A.E., 2002. Soil science in tropical and temperate regions-some differences and similarities. Advances in Agronomy, 77, 269-292.

Hodnett, M.G., da Silva, L.P., da Rocha, H.R., Cruz Senna, R., 1995. Seasonal soil water storage changes beneath central Amazonian rainforest and pasture: Journal of Hydrology, $170,1-4,233-254$.

Hodnett, M.G., Tomasella, J., 2002. Marked differences between van Genuchten soil water-retention parameters for temperate and tropical soils: a new water-retention pedotransfer functions developed for tropical soils. Geoderma, 108, 3, 155-180. 
Hopmans, J.W., Schoups, G., 2006. Soil Water Flow at Different Spatial Scales. In: Encyclopedia of Hydrological Sciences: John Wiley \& Sons.

Lal, R., 1979. Physical properties and moisture retention characteristics of some nigerian soils. Geoderma, 21, 3, 209223.

Lavigne, F., Gunnell, Y., 2006. Land cover change and abrupt environmental impacts on Javan volcanoes, Indonesia: a long-term perspective on recent events. Regional Environmental Change, 6, 1-2, 86-100.

Maeda, T., Takenaka, H., Warkentin, B.P., 1977. Physical properties of allophane soils. Advances in Agronomy, 29, C, 229-264.

Manrique, L.A., Jones, C.A., Dyke, P.T., 1991. Predicting soil water retention characteristics from soil physical and chemical properties. Communications in Soil Science and Plant Analysis, 22, 17-18, 1847-1860.

McBratney, A.B., Minasny, B., Cattle, S.R., Vervoort, R.W., 2002. From pedotransfer functions to soil inference systems. Geoderma, 109, 1-2, 41-73.

Minasny, B., Hartemink, A.E., 2011. Predicting soil properties in the tropics. Earth-Science Reviews, 106, 1, 52-62.

Nelson, D.W., Sommers, L.E., 1996. Total carbon, organic carbon, and organic matter. In: Sparks, D.L., Page, A.L., Helmke, P.A., Loeppert, R.H. (Eds.): Methods of Soil Analysis. Part 3: Chemical Methods. Soil Science Society of America, American Society of Agronomy, Madison, WI, pp. 961-1010.

Nguyen, P.M., Van Le, K., Botula, Y.-D., Cornelis, W.M., 2015. Evaluation of soil water retention pedotransfer functions for Vietnamese Mekong Delta soils. Agricultural Water Management, 158, 126-138.

Nugroho, P., 2015. Model soil water assessment tool (SWAT) untuk prediksi laju erosi dan sedimentasi sub das Keduang Kabupaten Wonogiri (SWAT model for erosion rate prediction in the Keduang sub catchment, Wonogiri residence). Universitas Muhammadiyah, Surakarta, $85 \mathrm{p}$.

Oldhoff, R.J.J., 2015. Local and catchment scale validation of soil hydraulic pedotransfer functions for an Indonesian watershed. University of Twente, Enschede, 96 p.

Pachepsky, Y., Rawls, W.J., (Eds.), 2004. Development of Pedotransfer Functions in Soil Hydrology. Elsevier, 542 p.

Pachepsky, Y., Schaap, M.G., 2004. Data mining and exploration techniques. In: Development of Pedotransfer Functions in Soil Hydrology. Elsevier, pp. 21-32.

Pidgeon, J.D., 1972. The measurement and prediction of available water capacity of Ferralitic soils in Uganda. Jurnal of Soil Science, 23, 431-441.

Rayment, G.E., Higginson, F.R., 1992. Australian laboratory handbook of soil and water chemical methods. Australian soil and land survey handbook. Inkata Press, Melbourne.

Richards, L.A., 1947. Pressure membrane apparatus, construction and use. Agric. Eng., 28, 451-454.
Richards, L.A., Fireman, M., 1943. Pressure-plate apparatus for measuring moisture sorption and transmission by soils. Soil Science, 56, 6, 395-404.

Suhardjo, H., Soepraptohardjo, M., 1981. Indonesian soil units and sub units for survey and mapping of transmigration areas. Bogor, Balai penelitian tanah, Departemen Pertanian Republik Indonesia (Soil Research Centre of the Ministry of Agriculture, Republic of Indonesia), 24 p.

Sulaeman, Y., Minasny, B., McBratney, A.B., Sarwani, M., Sutandi, A., 2013. Harmonizing legacy soil data for digital soil mapping in Indonesia. Geoderma, 192, 1, 77-85.

Tan, K.H., 2008. Soils in the humid tropics and monsoon region of Indonesia. CRC Press, $584 \mathrm{p}$.

Tomasella, J., Hodnett, M.G., 1998. Estimating soil water retention characteristics from limited data in Brazilian Amazonia. Soil Science, 163, 190-202.

Tomasella, J., Hodnett, M., 2004. Pedotransfer functions for tropical soils. In: Development of Pedotransfer Functions in Soil Hydrology. Elsevier, pp. 415-429.

Tomasella, J., Hodnett, M.G., Rossato, L., 2000. Pedotransfer functions for the estimation of soil water retention in Brazilian soils. Soil Science Society of America Journal, 64, $1,327$.

Tranter, G., McBratney, A.B., Minasny, B., 2009. Using distance metrics to determine the appropriate domain of pedotransfer function predictions. Geoderma, 149, 3-4, 421-425.

van Bemmelen, R.W., 1949. Geology of Indonesia. Vol. IA general geology. SDU, The Hague, $732 \mathrm{p}$.

van den Berg, M., Klamt, E., van Reeuwijk, L.P., Sombroek, W.G., 1997. Pedotransfer functions for the estimation of moisture retention characteristics of Ferralsols and related soils. Geoderma, 78, 3-4, 161-180.

van Engelen, V.W.P., Ting-tiang, W., 1995. Global and national soils and terrain digital databases (SOTER) Procedures manual: no. 74 (rev. 1), 122 p.

van Genuchten, M.T., 1980. A closed-form equation for predicting the hydraulic onductivity of unsaturated soils. Soil Science Society of America Journal, 44, 5, 892-898.

van Genuchten, M.T., Leij, F.J., Yates, S.R., 1991. The RETC code for quantifying the hydraulic functions of unsaturated soils, version 1.0. Riverside, $93 \mathrm{p}$.

Vernimmen, R., BMKG, 2013. Joint cooperation programme component D1: droughts early warning system. $36 \mathrm{p}$.

Wösten, J.H.M., Pachepsky, Y.A., Rawls, W.J., 2001. Pedotransfer functions: bridging the gap between available basic soil data and missing soil hydraulic characteristics. Journal of Hydrology, 251, 3-4, 123-150.

Wösten, J.H.M., Verzandvoort, S.J.E., Leenaars, J.G.B., Hoogland, T., Wesseling, J.G., 2013. Soil hydraulic information for river basin studies in semi-arid regions. Geoderma, 195-196, 79-86. 